Introduction

\title{
The RESET project: constructing a European tephra lattice for refined synchronisation of environmental and archaeological events during the last c. $100 \mathrm{ka}$
}

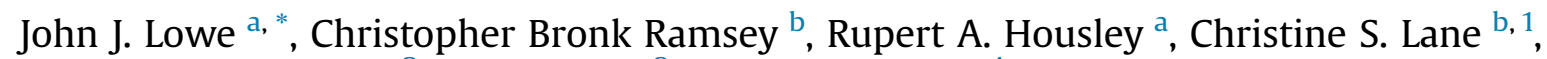 \\ Emma L. Tomlinson ${ }^{\mathrm{c}, 2}$, RESET Team ${ }^{3}$, RESET Associates ${ }^{4}$ \\ a Centre for Quaternary Research, Geography Department, Royal Holloway, University of London, Egham, Surrey, TW20 0EX, UK \\ ${ }^{\mathrm{b}}$ Research Laboratory for Archaeology and the History of Art, University of Oxford, Dyson Perrins Building, South Parks Road, Oxford, OX1 3QY, UK \\ ${ }^{\mathrm{c}}$ Department of Earth Sciences, Royal Holloway, University of London, Egham, Surrey, TW20 0EX, UK
}

\section{A R T I C L E I N F O}

\section{Article history:}

Available online 8 May 2015

\section{Keywords:}

Last Glacial stage

Dansgaard-Oeschger and Heinrich events

Abrupt environmental transitions (AETs)

Middle to Upper Palaeolithic

Volcanic ash isochrons

Tephra geochemistry

Tephra database

\begin{abstract}
A B S T R A C T
This paper introduces the aims and scope of the RESET project (RESponse of humans to abrupt Environmental Transitions), a programme of research funded by the Natural Environment Research Council (UK) between 2008 and 2013; it also provides the context and rationale for papers included in a special volume of Quaternary Science Reviews that report some of the project's findings. RESET examined the chronological and correlation methods employed to establish causal links between the timing of abrupt environmental transitions (AETs) on the one hand, and of human dispersal and development on the other, with a focus on the Middle and Upper Palaeolithic periods. The period of interest is the Last Glacial cycle and the early Holocene (c. 100-8 ka), during which time a number of pronounced AETs occurred. A long-running topic of debate is the degree to which human history in Europe and the Mediterranean region during the Palaeolithic was shaped by these AETs, but this has proved difficult to assess because of poor dating control. In an attempt to move the science forward, RESET examined the potential that tephra isochrons, and in particular non-visible ash layers (cryptotephras), might offer for synchronising palaeo-records with a greater degree of finesse. New tephrostratigraphical data generated by the project augment previously-established tephra frameworks for the region, and underpin a more evolved tephra 'lattice' that links palaeo-records between Greenland, the European mainland, sub-marine sequences in the Mediterranean and North Africa. The paper also outlines the significance of other contributions to this special volume: collectively, these illustrate how the lattice was constructed, how it links with cognate tephra research in Europe and elsewhere, and how the evidence of tephra isochrons is beginning to challenge long-held views about the impacts of environmental change on humans during the Palaeolithic.
\end{abstract}

(c) 2015 Elsevier Ltd. All rights reserved.

\section{Introduction}

This paper sets the context for a special volume of Quaternary Science Reviews that is dedicated to some of the key outcomes of the

\footnotetext{
* Corresponding author. Tel.: +44 1784 443565/443563.

E-mail address: j.lowe@rhul.ac.uk (J.J. Lowe).

1 Current address: School of Environment, Education \& Development, University of Manchester, Arthur Lewis Building, Oxford Road, M13 9PL, UK.

2 Current address: Department of Geology, Trinity College Dublin, College Green, Dublin 2, Ireland.

3 See Appendix 1.

4 See Appendix 2.
}

RESET project (RESponse of humans to abrupt Environmental Transitions), an inter-disciplinary and inter-institutional programme of research funded by the Natural Environment Research Council (NERC, UK) between 2008 and 2013 (http://c14.arch.ox.ac. $\mathrm{uk} /$ reset). RESET examined the methods generally employed to establish causal links between the timing of abrupt environmental transitions (AETs) on the one hand, and stages in human dispersal and development on the other, with a focus on the Middle and Upper Palaeolithic periods. These encompass the Last Glacial cycle and the early Holocene (c. 100-8 ka), during which time a number of abrupt climatic oscillations occurred. The last glacial stage witnessed no fewer than 25 significant climatic oscillations between 
stadial and interstadial conditions (Dansgaard-Oeschger or D-O events; Fig. 1), the latter characteristically initiated by sudden thermal ameliorations of between 5 and $16{ }^{\circ} \mathrm{C}$ and usually accomplished within just a few decades (Steffensen et al., 2008; Rasmussen et al., 2014). During the latter part of the Last Glacial stage, a series of six extremely severe climatic interludes, lasting up to a few centuries and termed Heinrich Events $(\mathrm{H})$, impacted not only on the North Atlantic region (Hemming, 2004), but also further afield, including the circum-Mediterranean area (Bartov et al., 2003; Llave et al., 2006).

The environmental consequences of this erratic pattern of climatic behaviour, and the degree to which it may have shaped human evolution and endeavours during the Palaeolithic, are key questions in current scientific debate. Important and controversial threads within this developing discourse include the origins and spread of modern humans (e.g. Smith et al., 2005; Trinkaus, 2005; Carto et al., 2009; Hoffecker, 2009); the causes of human demographic fluctuations (e.g. Blockley et al., 2006; Blome et al., 2012; Eriksson et al., 2012) and of sudden cultural innovations (e.g. Richerson et al., 2009); the possible link between those developments and extinction of the Neanderthals (e.g. Herrera et al., 2009; Golovanova et al., 2010; Stringer, 2011; Hublin, 2012); and the birth and spread of early agriculture (Weninger et al., 2009; Blockley and Pinhasi, 2011). It is even hypothesised that some stages in human development can be attributed, at least in part, to individual AETs triggered, for example, by climatic influences (e.g. Tzedakis et al., 2007; Hoffecker, 2009), volcanic catastrophe (Golovanova et al., 2010; Fitzsimmons et al., 2013) or a combination of both (e.g. Fedele et al., 2002, 2008; Costa et al., 2012).

In theory, it should be possible to test such hypotheses by establishing the precise temporal relationships between archaeological events and AETs, but this has long proved an elusive goal because of the imprecise nature of age estimates obtained for events dating to within the Last Glacial period, especially those at around or beyond the limit of radiocarbon dating (c. $50 \mathrm{ka}{ }^{14} \mathrm{C} \mathrm{BP}$ ). Although a number of dating methods, including radiocarbon, have been considerably refined in recent years (e.g. Higham et al., 2011, 2012), it nevertheless remains the case that the great majority of published age estimates for events dating to within the Last Glacial stage have wide uncertainty ranges - typically centennial to millennial in magnitude. Furthermore, the true error ranges could exceed the published values, for the majority of the latter tend to reflect only the uncertainty associated with the precision of analytical (radiometric) measurement; additional uncertainty arises if sample integrity has been compromised by, for example, secondary deposition or in situ contamination, though these factors are frequently difficult to detect or to quantify (Lowe et al., 2007). In combination, these constraints lead to frustratingly low chronological precision, which tends to obscure the detailed phase relationships between environmental and archaeological events.

The annually-resolved Greenland ice-core record constitutes perhaps the best available chronometer for the complex sequence of climatic perturbations that characterised the Last Glacial cycle, and has therefore been proposed as the most appropriate stratotype for this period, against which other records should be compared (Lowe et al., 2008; Blockley et al., 2012; Rasmussen et al., 2014). However, the Greenland chronograph is also subject to computational errors as a result of (i) possible gaps in the iceaccumulation record, (ii) annual layers that are thin or indistinct and therefore difficult to resolve, and (iii) operator bias. In combination, these difficulties give rise to uncertainty values, termed Maximum Counting Errors (MCE), that are directly proportional to the number of layers counted and hence increase progressively with age (depth in the ice core). The estimated MCE values for the Greenland stratotype sequence are around 100 years at $11 \mathrm{ka}$, 900 years at $30 \mathrm{ka}$ and $>2000$ years at $50 \mathrm{ka} \mathrm{b2k}$ (Rasmussen et al., 2006, 2014; Seierstad et al., 2014). Comparisons between the Greenland stratotype sequence and other records therefore need to take account of the uncertainties that compromise each data-set, as illustrated schematically in Fig. 2. This shows (a) age estimates and corresponding MCE values for the onsets of Greenland Interstadials 11 and 8, based on the Greenland ice-core (GICC05) timescale of Blockley et al. (2012); and (b) hypothetical but typical radiometric age estimates and $2 \sigma$ error ranges obtained for presumed equivalent horizons in a different type of record. The compound statistical error ranges obtained by combining the GICC05 and radiometric age uncertainties are 2906 years for the start of GI-11 and 2293 years for the start of GI-8. These values greatly exceed the durations of the abrupt warming phases that prefaced both interstadials, estimated to have lasted c. 400 and 100 GICC05 ice-core years respectively (Fig. 2), and the events commonly targeted for dating or correlation. Indeed, the uncertainty ranges even exceed the durations of the entire interstadial episodes, estimated to have lasted c.1100 and 1640 GICC05 ice-core years respectively (after Blockley et al., 2012).

Given these uncertainties, it has proved rarely possible, when employing standard geological dating methods, to resolve events dating to the Last Glacial stage on a sub-centennial timescale. Most so-called 'high-resolution' reconstructions of past environmental change either ignore the true scale of uncertainty in the age models

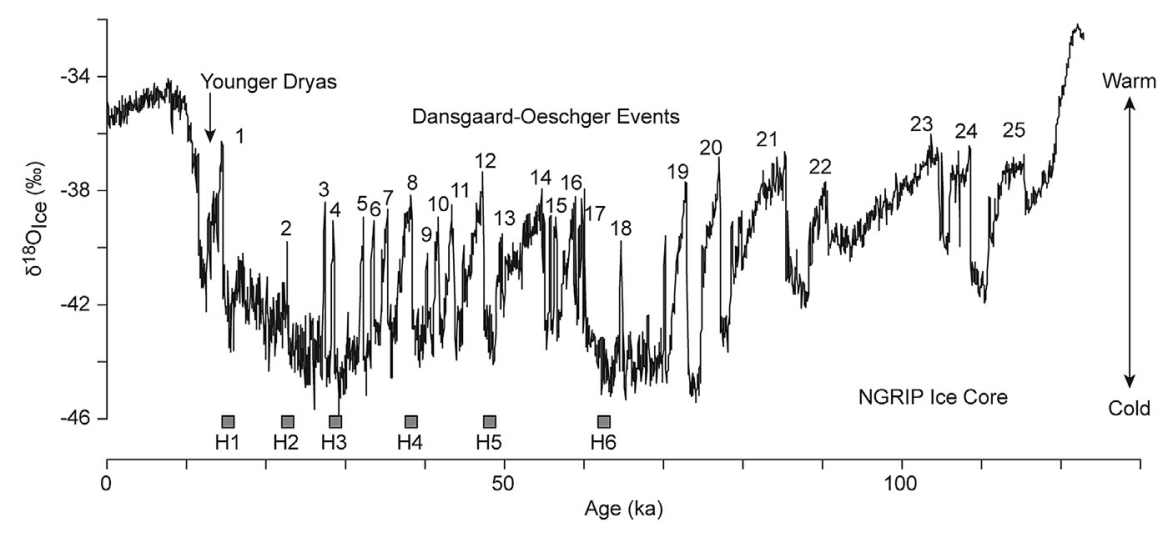

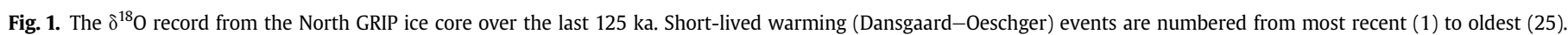

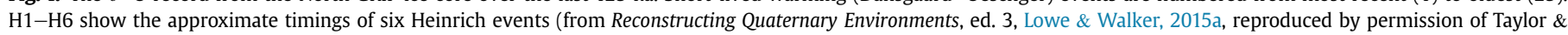
Francis Books UK) and based on an original figure in Clement and Peterson (2008). 


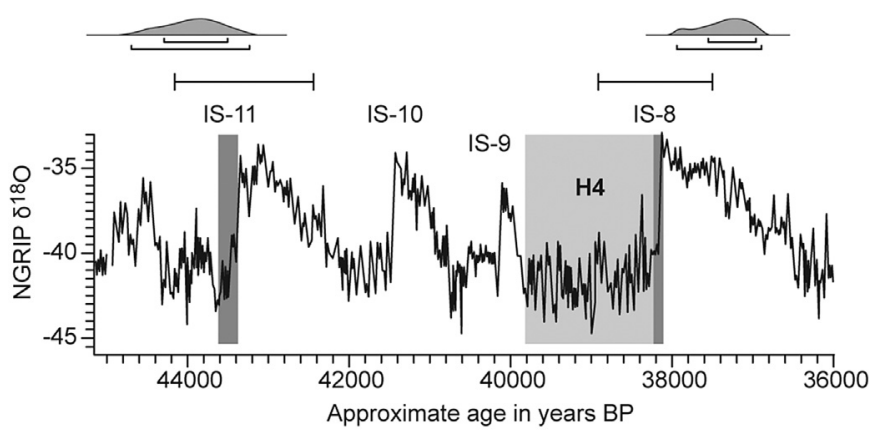

$\longmapsto$ MCE range Radiocarbon age probability curve

Fig. 2. The segment of the Greenland isotope curve spanning interstadials (IS) 8-11. The abrupt warming phases at the start of IS- 8 and IS- 11 are shaded dark grey. The duration of $\mathrm{H} 4$ is represented by the light grey shading. The length of the line bars above the IS labels represent the MCE ranges for GICC05 ages of the abrupt warming events. Typical radiocarbon age probability distributions for events of comparable age are shown at top, with bars representing $1 \sigma$ (upper bar) and $2 \sigma$ errors. The degree to which the radiocarbon and ice-core age estimates are compatible is subject to the laws of the combination of statistical errors: for further explanation see text. The diagram is partly based on Figure. 3 of Wood et al., 2013.

used, or rely on visual 'matching' (alignment) of records. The latter approach employs what are considered to be isochronous environmental 'markers', for example the onsets and terminations of D-O or Heinrich events, to synchronise diverse records. However, this approach presumes rather than tests the degree of synchronicity between them, and consequently precludes the possibility of revealing any short-term phase differences (leads and lags) affecting past climatic behaviour or concomitant environmental or human responses (Blaauw, 2012; Austin and Hibbert, 2012; Lowe and Walker, 2015b). Until more robust approaches are developed, therefore, answers to some of the most vital and intriguing questions about our recent past, and understanding fully their implications for the future, are likely to remain tantalisingly beyond our grasp. RESET attempted to move the science forward by seeking ways to reduce the chronological uncertainty that compromises archaeological and palaeo-environmental records, and their integration. To achieve this, RESET adopted and developed the use of tephra isochrons as the main tool in its research strategy, for reasons developed in the following section. Subsequent sections of the paper will provide more detail on the structure and strategy adopted in the RESET project (Section 3), outline the development of the tephrostratigraphical framework, or lattice, that RESET has helped to advance (Section 4), consider the extent to which the lattice provides a basis for independent alignment of stratigraphical records (Section 5) and speculate on the prospects for synchronising records with greater chronological finesse in the future, using the RESET approach (Section 6).

\section{The importance of tephra isochrons}

Tephrochronology-the tracing and dating of dispersed volcanic ash layers within and between geological sequences - has long served to underpin the chronology and correlation of late Quaternary records in various parts of the world (Lowe, 2011; Alloway et al., 2013). Until comparatively recently, this work rested almost exclusively on the analysis of visible ash layers, only a few of which could be detected over wide areas. More recently, advances in methods that enable the detection and chemical classification of non-visible ash layers (cryptotephras), composed predominantly of microscopic tephra shards, has greatly extended the geographical dispersal ranges over which some layers can now be traced (frequently termed the 'footprint' of the volcanic eruption from which an individual ash layer was derived). It also increases the likelihood of detecting tephra layers in places where they are not preserved as visible layers because of taphonomic issues and/or sedimentation rates. The idea of the RESET project germinated from embryonic cryptotephra research conducted in Europe, the results of which were beginning to extend the footprints of some Icelandic tephras across larger swathes of northern Europe in particular (Davies et al., 2002; Turney et al., 2004). Other related work demonstrated that multiple cryptotephra layers are preserved in marine deposits in the Mediterranean Sea, in some sequences outnumbering their visible counterparts; these had previously evaded detection by routine down-core scanning and logging procedures (Lowe et al., 2007; Bourne et al., 2010). A further notable advance was the growing number of cryptotephra layers that could be dated robustly in key sites, such as in the Greenland ice-core records (Abbott and Davies, 2012); these ages can be imported into other records containing the equivalent tephra layers, where dating is less reliable. This approach therefore offers the potential for refinement and/or independent testing of site chronologies (e.g. Lowe, 2001; Blockley et al., 2008). However, these developments prompted a number of questions about the fuller potential of cryptotephra investigations, with respect, for example, to: (a) the number of volcanic eruptions that have left traceable cryptotephra footprints; (b) the maximal areas over which they can be traced; (c) the factors influencing their preservation; (d) whether they represent primary ash fall events or secondary re-deposition processes; (e) the degree to which they can be satisfactorily differentiated using chemical discrimination methods; and (f) the range of sedimentary repositories in which they are preserved.

With these questions in mind, RESET set out to explore the scope that cryptotephra layers offered for extending existing, or providing new, time-synchronous markers (isochrons) between archaeological and palaeoenvironmental records, building on earlier frameworks initiated by, for example, Keller et al. (1978) and Paterne et al. (1988) in the Mediterranean area, and Haflidason et al. (2000) and Davies et al. (2002) in northern Europe and the North Atlantic. Key aspirations included: (i) extending tephra footprints into new areas that previously had lain beyond the limits of dispersal of visible ash layers; (ii) increasing the number of tephra isochrons that could be used for synchronising diverse sedimentary archives; and (iii) exploring new sedimentary repositories, for example soil, cave and rock shelter deposits, for the presence of cryptotephra layers. For the project to succeed, individual tephra layers should be (a) chemically or physically distinctive, (b) widespread, (c) well preserved in discrete layers and (d) of known (quantified) age or capable of being dated precisely. RESET's first task, therefore, was to identify which key tephra layers best satisfied these criteria and therefore provided the highest potential for enhancing the framework or lattice of isochronous marker horizons linking diverse sedimentary records throughout Europe and its adjacent seas.

At present around 100 tephra layers of different age, originating from European volcanic centres, have been detected in stratigraphical sequences that collectively span the period of interest to RESET (see Figures 1 and 2 in Blockley et al., 2014). Most of these were known to the RESET team at the commencement of the project, but it was immediately evident that very few met all of the criteria alluded to above. For example, not all had been unequivocally characterised by chemical analytical methods or traced to source, while the ages of some were contested or not well known (Bronk Ramsey et al., 2015a). Furthermore, it was not clear at that time which of the tephra layers could be detected more widely, including in archaeological contexts, with the exception of the products of some of the larger volcanic eruptions, such as the 
Campanian Ignimbrite, dated to around 39 ka (De Vivo et al., 2001), and the Neapolitan Yellow Tuff, dated to around $14.2 \mathrm{ka}$ (Siani et al., 2004). Since time and resources would not have enabled a comprehensive examination of all the known tephra layers spanning the Last Glacial cycle, a selective strategy that focused on those tephras considered to optimise the potential for synchronising records was clearly necessary, and is described next.

\section{The strategy and structure adopted in the RESET project}

For the RESET project's overall aims to be realised within the funded period (5 years), several co-dependent, strategic prerequisites had to be met. First, archaeological and palaeoenvironmental events based on secure evidence and with wide geographical impacts needed to be identified, in sequences that were also accessible for tephrostratigraphical sampling. Second, the archaeological events should occur within time windows characterised by marked AETs that also impacted over wide areas. Third, preference should be given to sequences in which several tephras could be detected, providing the potential for a number of isochronous tie-lines between them. Fourth, the sequences selected for study must satisfy a number of stratigraphical and sample preservation conditions, in order to optimise the potential for developing age models of sub-centennial resolution. The only feasible way to successfully address these co-prerequisites, develop the tephra lattice, and test its success in the time available, was by basing the study on existing records for which detailed stratigraphical contexts and appropriate palaeoenvironmental information were already available. An additional consideration was the multi-disciplinary nature of the project, requiring combination of expertise in Palaeolithic archaeology, palaeoclimatology, palaeoceanography, volcanic ash detection, high-precision geochemistry, statistical discrimination methods, geochronology and agemodelling routines. It was for these reasons that a consortium approach was considered essential, and subsequently approved for funding by the NERC.

The RESET consortium was co-ordinated by the personnel listed in Appendix 1, and organised under the following seven workpackages:

WP-1: Neanderthals \& modern humans in Europe, 60-25 ka

WP-2: The impact of AETs on early modern human populations in North Africa

WP-3: Re-populating Europe after the Last Glacial Stage

WP-4: Geochemical fingerprinting of tephras

WP-5: AETs and tephras in marine sediment cores

WP-6: AETs and tephras in continental records

WP-7: Data synthesis and age modelling.

These seven themes provided a coherent framework for maintaining focus on the key tasks and goals of the RESET project, while ensuring co-ordinated interactions between field and laboratory personnel (Fig. 3). WPs 1-3 focused on major archaeological events selected as optimal for RESET's aims because they fulfilled the criteria outlined above. Two of the topics also fall within the range of the radiocarbon timescale, while several diagnostic tephras were known to have coincided with each event (see Fig. 5). WPs 4, 5 and 6 developed the tephrostratigraphical framework that underpinned the project. Here the emphasis was on maintaining, and indeed advancing, quality assurance protocols for the detection, extraction and geochemical 'fingerprinting' of selected tephras, and for refining their chronology. WP-7 used Bayesian modelling procedures to combine all of the stratigraphical and geochronological information harvested within the project, to generate best-estimate age models for individual site
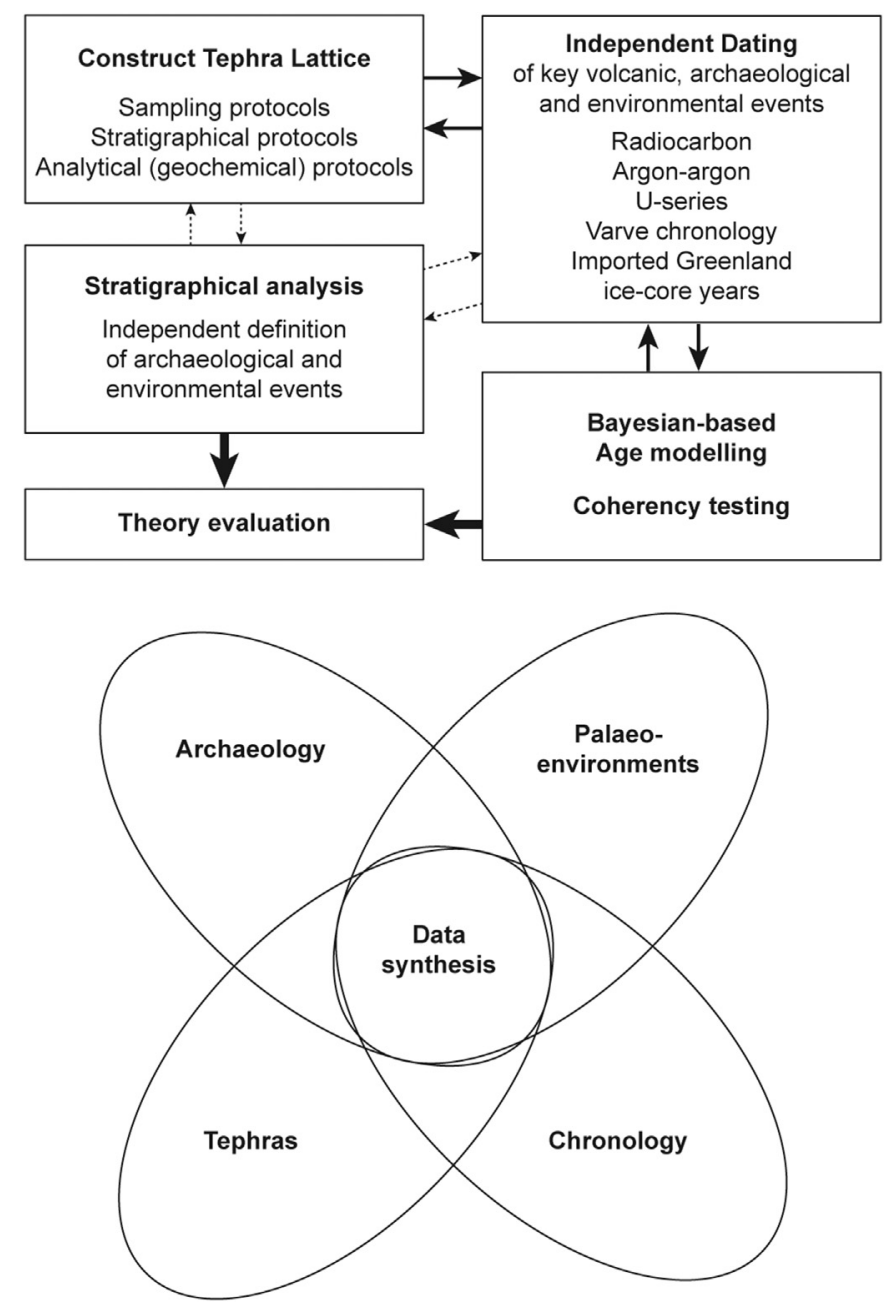

Fig. 3. Schematic representation of the science structure (top) and work-package integration (bottom) adopted in the RESET project.

records, and to test proposed synchronisations between archaeological events and AETs.

Effective co-ordination was also essential for liaison with the very large number of collaborators involved in the project. RESET's goals could not have been achieved without the strategic involvement of numerous personnel based in various institutions throughout Europe (listed in Appendix 2). Collectively, they (i) provided access to key sites and records, some of which have protected status; (ii) assisted in the identification and selection of optimal horizons, layers or samples for analysis; (iii) contributed additional (often unpublished) data for the project database (Section 4.4); and (iv) participated in project workshops in which the collective data were screened, classified and synthesised. As a result, RESET was able to obtain and collate information from 146 sites, comprising archaeological (mostly cave or rock-shelter) sequences, other terrestrial records (e.g. lake, paludal and soil deposits), proximal volcanic fall deposits in 21 volcanic centres and borehole records from seven marine core stations, collectively providing baseline data extending through much of Europe and the Mediterranean Sea to North Africa (Fig. 4; Table 1). Without this extensive collaborative effort and network, the RESET team would not have been able to collect and collate the amount of data that it did, which is why all of the collaborators are not only acknowledged here, but are considered co-producers of this summary report. In the section that follows, we summarise some of the key objectives 


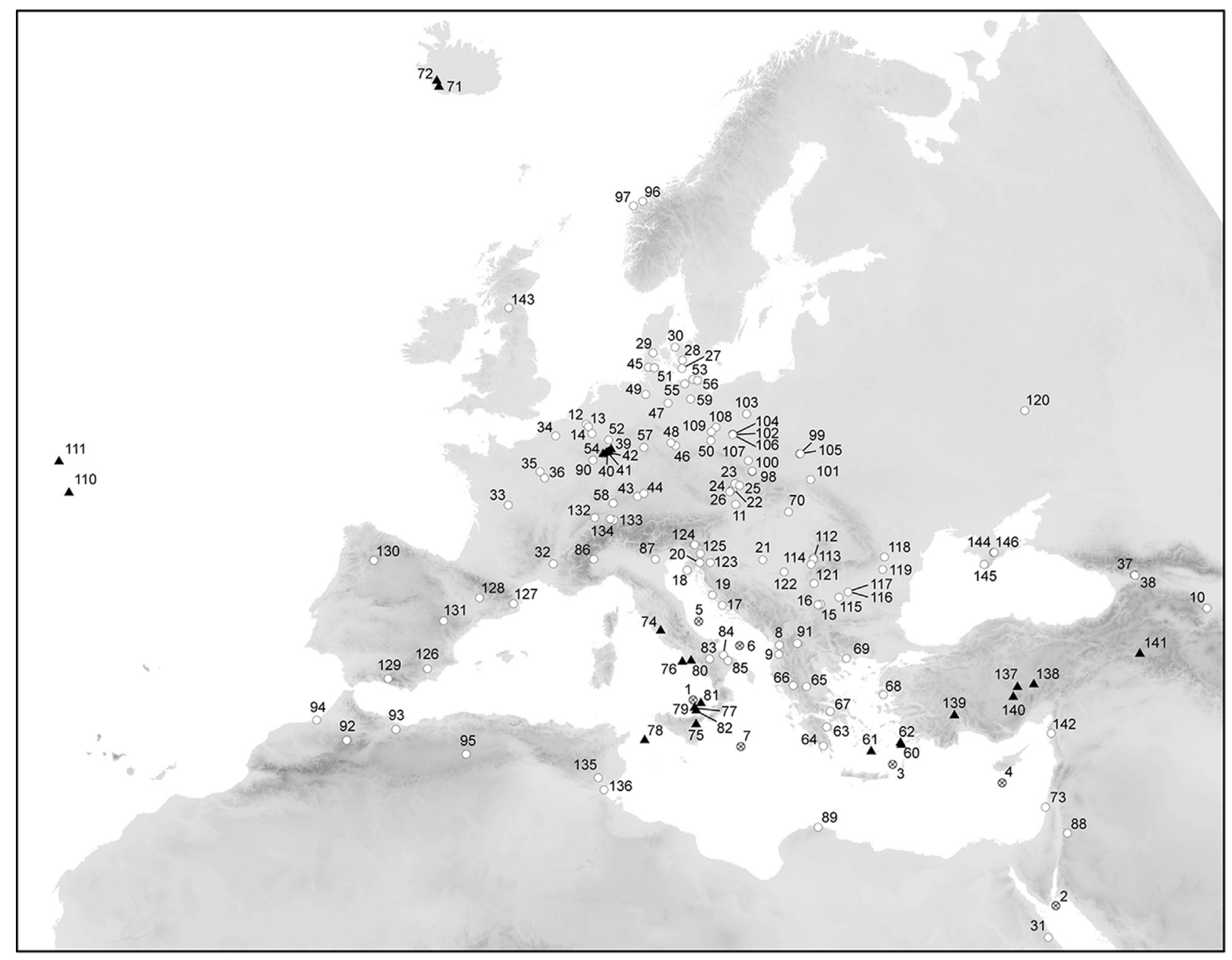

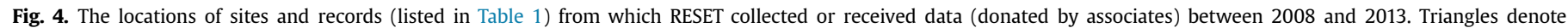
approximate positions of volcanic centres, circles with a cross are marine core stations, and open circles are terrestrial (including archaeological) sites.

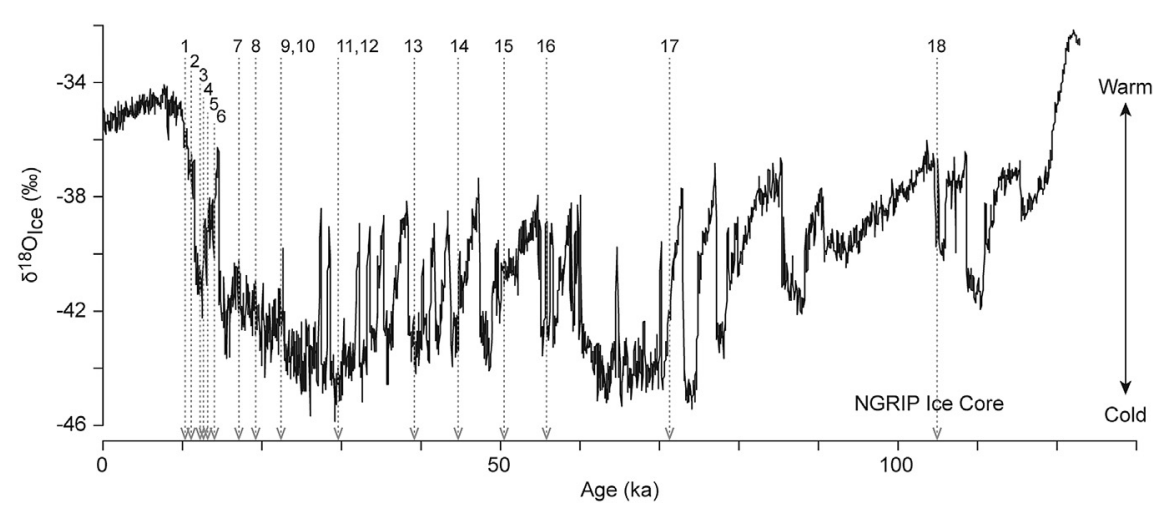

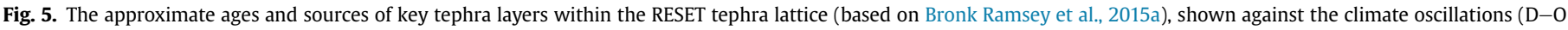

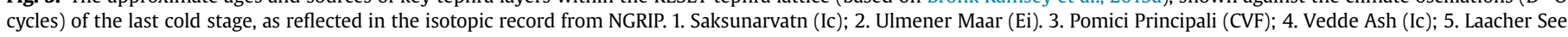

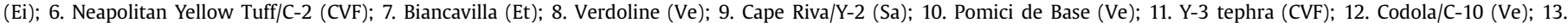

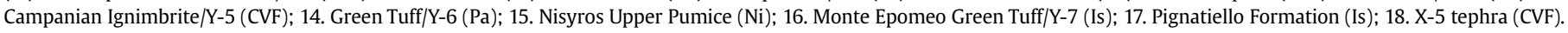
CVF - Campanian Volcanic Field; Ic - Iceland; Ei - Eiffel; Et - Etna; Ve - Vesuvius; Pa - Pantelleria; Ni - Nisyros; Is - Ischia; Sa - Santorini. 


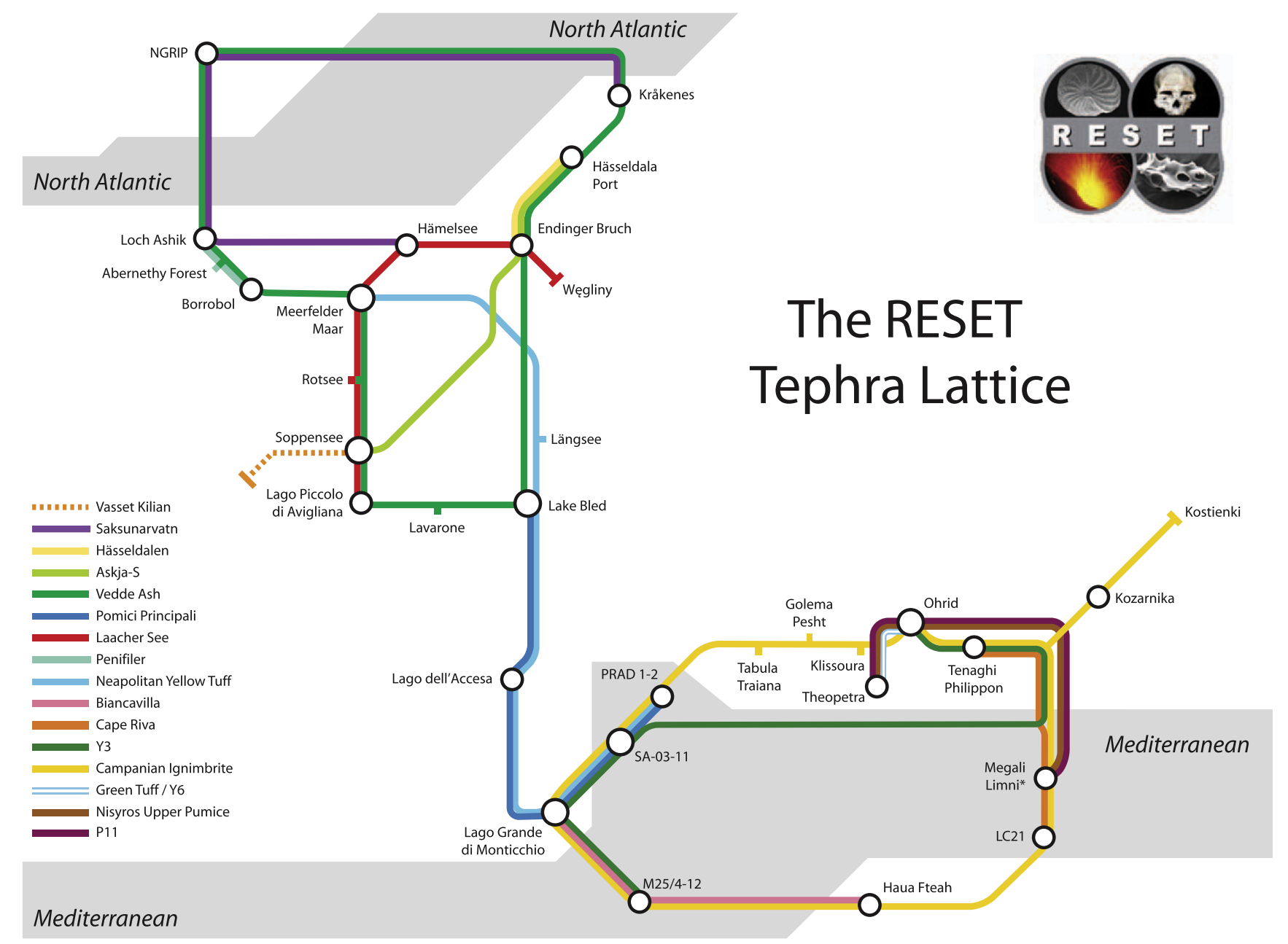

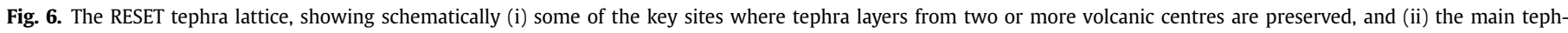
rostratigraphical links throughout Europe and the Mediterranean region.

and findings of RESET, but with the main emphasis on the tephrostratigraphical research, because it is the tephra lattice that enables a fresh examination of the palaeoenvironmental and archaeological issues alluded to earlier.

\section{Building the RESET tephra lattice}

\subsection{Tephrostratigraphical constraints}

The study of cryptotephra layers presents significant technical challenges, not least because the very small size of the glass shards they normally contain (long axis frequently much less than $100 \mu \mathrm{m}$ ) requires the application of very exacting laboratory procedures, first to isolate the shards (Blockley et al., 2005), and then to capture precise and reliable geochemical data from them (Pearce et al., 2007; Tomlinson et al., 2010; Hayward, 2011). Micron-scale measurement of small vesicular shards can prove particularly problematic because thin vesicle walls and junctions limit the surface area on which to focus a microprobe beam, while subsurface vesicles limit the vertical thickness available for analysis and microcrysts at or below the surface can contaminate sample aliquots (Tomlinson et al., 2010). Furthermore, the number of cryptotephra shards available for analysis can be exceedingly low in ultra-distal sites.
Other procedural difficulties also needed to be confronted. First, the reliable identification of distal tephra layers rests predominantly on establishing a robust chemical match with proximal volcanic material, using consistent and very precise geochemical measurements. But it was clear from the start of the project that proximal records for some eruption phases were far from comprehensive or were based on analysis of whole rock rather than glass samples, and thus new work had to be undertaken to augment eruption data for candidate proximal equivalents of selected distal ash layers. Secondly, little was known about the possibility of strong chemical gradients between proximal and distal members of the same eruption event; attention therefore needed to be paid to this factor, as well as to the fact that the chemical composition of eruptives from the same volcanic source evolves over time. Third, some of the tephra layers discovered during the work of RESET were not initially represented in the proximal record, or were represented by proximal layers that had not yet been dated satisfactorily. Attempts were therefore made to refine the ages of some layers, where necessary. Fourth, successive eruptions from single volcanic centres, particularly long-lived magma systems such as the Campi Flegrei near Naples, can generate products with very similar chemical compositions. This can seriously constrain the ability to match individual proximal and distal layers. Fifth, the matching process itself, which relies on the 
Table 1

List of sites and records which RESET studied between 2008 and 2013 or for which data were donated by project associates. Site names in italics are volcanic centres.

\begin{tabular}{|c|c|c|c|c|c|c|c|}
\hline Site number & Site name & General location & Work package & Site number & Site name & General location & Work package \\
\hline 1 & TIR2000-C01 & Marine core & 4 & 74 & Alban Hills & Italy & 4 \\
\hline 2 & KL17 & Marine core & 5 & 75 & Etna & Italy & 4 \\
\hline 3 & LC21 & Marine core & 5 & 76 & Ischia & Italy & 4 \\
\hline 4 & ODP 967 & Marine core & 5 & 77 & Lipari & Italy & 4 \\
\hline 5 & PRAD 1-2 & Marine core & 5 & 78 & Pantelleria & Italy & 4 \\
\hline 6 & SA03-11 & Marine core & 5 & 79 & Salina & Italy & 4 \\
\hline 7 & M25/4-11 & Marine core & 4 & 80 & Somma-Vesuvius & Italy & 4 \\
\hline 8 & Blaz cave & Albania & 1 & 81 & Stromboli & Italy & 4 \\
\hline 9 & Shpella e Zeze Cave & Albania & 1 & 82 & Vulcano & Italy & 4 \\
\hline 10 & Azokh Cave & Armenia & 1 & 83 & Lago Grande di Monticchio & Italy & 4 \\
\hline 11 & Grub-Kranawetberg & Austria & 1 & 84 & Grotta di Santa Croce & Italy & 1 \\
\hline 12 & Arendonk De Liereman & Belgium & 3 & 85 & Riparo l'Oscurusciuto & Italy & 1 \\
\hline 13 & Lommel Maatheide & Belgium & 3 & 86 & Lago Piccolo di Avigliana & Italy & 6 \\
\hline 14 & Opgrimbie & Belgium & 3 & 87 & Lake Fimon & Italy & 6 \\
\hline 15 & Kozarnika & Bulgaria & 1 & 88 & Ain Difla & Jordan & 1 \\
\hline 16 & Redaka II & Bulgaria & 1 & 89 & Haua Fteah & Libya & 2 \\
\hline 17 & Mujina pećina & Croatia & 1 & 90 & Alzette valley & Luxembourg & 3 \\
\hline 18 & Romualdova pećina & Croatia & 1 & 91 & Golema Pešt & Macedonia & 1 \\
\hline 19 & Velika pećina in Klićevica & Croatia & 1 & 92 & Lake Ifrah & Morocco & 2 \\
\hline 20 & Erdut & Croatia & 6 & 93 & Taforalt & Morocco & 2 \\
\hline 21 & Zmajevac & Croatia & 6 & 94 & Dar-es-Soltan I & Morocco & 2 \\
\hline 22 & Bohunice-Brno 2002 & Czech Republic & 1 & 95 & Rhafas Cave & Morocco & 2 \\
\hline 23 & Kůlna Cave & Czech Republic & 1 & 96 & Dimna Bog & Norway & 6 \\
\hline 24 & Moravský Krumlov & Czech Republic & 1 & 97 & Krakenes & Norway & 6 \\
\hline 25 & Želeč/Ondratice I & Czech Republic & 1 & 98 & Lubotyn 11 & Poland & 1 \\
\hline 26 & Vedrovice 5 & Czech Republic & 1 & 99 & Cmielow 95 & Poland & 3 \\
\hline 27 & Hasselø & Denmark & 3 & 100 & Dzierzyslaw 35 & Poland & 3 \\
\hline 28 & Lundby Mose & Denmark & 3 & 101 & Hlomcza & Poland & 3 \\
\hline 29 & Slotseng & Denmark & 3 & 102 & Legon 5 & Poland & 3 \\
\hline 30 & Staal se Kalunborg & Denmark & 6 & 103 & Mirkowice 33 & Poland & 3 \\
\hline 31 & Sodmein Cave & Egypt & 2 & 104 & Olbrachcice 8 & Poland & 3 \\
\hline 32 & Grotte Mandrin & France & 1 & 105 & Podgrodzie 16 & Poland & 3 \\
\hline 33 & Les Cottes & France & 1 & 106 & Siedlnica $17 / 17 \mathrm{~A}$ & Poland & 3 \\
\hline 34 & Dourges & France & 3 & 107 & Sowin 7 & Poland & 3 \\
\hline 35 & Étiolles & France & 3 & 108 & Strumienno & Poland & 3 \\
\hline 36 & Pincevent & France & 3 & 109 & Wegliny & Poland & 3 \\
\hline 37 & Bondi Cave & Georgia & 1 & 110 & Sete Cidades, Azores & Portugal & 4 \\
\hline 38 & Undo Cave & Georgia & 1 & 111 & Terceira, Azores & Portugal & 4 \\
\hline 39 & Laacher See & Germany & 4 & 112 & Coşava & Romania & 1 \\
\hline 40 & Meerfelder Maar & Germany & 4 & 113 & Romanesti-Dumbravita I & Romania & 1 \\
\hline 41 & Pulver maar & Germany & 4 & 114 & Tincova & Romania & 1 \\
\hline 42 & Ulmener Maar & Germany & 4 & 115 & Caciulatesti & Romania & 6 \\
\hline 43 & Hohle Fels & Germany & 1 & 116 & Daneasa & Romania & 6 \\
\hline 44 & Hohlenstein-Stadel & Germany & 1 & 117 & Draganesti-Olt & Romania & 6 \\
\hline 45 & Ahrenshöft & Germany & 3 & 118 & Focsanei & Romania & 6 \\
\hline 46 & Breitenbach & Germany & 3 & 119 & Sageata & Romania & 6 \\
\hline 47 & Grabow & Germany & 3 & 120 & Kostenki 14 & Russia & 1 \\
\hline 48 & Lengefeld & Germany & 3 & 121 & Tabula Traiana & Serbia & 1 \\
\hline 49 & Oldendorf & Germany & 3 & 122 & Titel Loess Plateau & Serbia & 6 \\
\hline 50 & Reichwalde & Germany & 3 & 123 & Griblje Marsh & Slovenia & 6 \\
\hline 51 & Tolk & Germany & 3 & 124 & Lake Bled & Slovenia & 6 \\
\hline 52 & Wesseling-Eichholz & Germany & 3 & 125 & Na Mahu & Slovenia & 6 \\
\hline 53 & Endinger Bruch (HBG) & Germany & 6 & 126 & Cueva Antón & Spain & 1 \\
\hline 54 & Meerfelder Maar Cores & Germany & 6 & 127 & L'Arbreda & Spain & 1 \\
\hline 55 & Potremser Moor & Germany & 6 & 128 & Estanya & Spain & 6 \\
\hline 56 & Reinberg & Germany & 6 & 129 & Padul & Spain & 6 \\
\hline 57 & Rothenkirchen & Germany & 6 & 130 & Sanabria & Spain & 6 \\
\hline 58 & Rotmeer & Germany & 6 & 131 & Villarquemado & Spain & 6 \\
\hline 59 & Zerrinsee bei Qualzow & Germany & 6 & 132 & Hauterive/Rouges-Terres & Switzerland & 3 \\
\hline 60 & Nisyros & Greece & 4 & 133 & Rotsee & Switzerland & 6 \\
\hline 61 & Santorini & Greece & 4 & 134 & Soppensee & Switzerland & 6 \\
\hline 62 & Yali & Greece & 4 & 135 & Ain el Guettar & Tunisia & 2 \\
\hline 63 & Klissoura 1 & Greece & 1 & 136 & El Akarit & Tunisia & 2 \\
\hline 64 & Lakonis 1 & Greece & 1 & 137 & Acigöl & Turkey & 4 \\
\hline 65 & Theopetra & Greece & 1 & 138 & Erciyes Dagi & Turkey & 4 \\
\hline 66 & Ioannina & Greece & 6 & 139 & Gölcük & Turkey & 4 \\
\hline 67 & Kopais Basin & Greece & 6 & 140 & Hasan Dagi & Turkey & 4 \\
\hline 68 & Megali Limni & Greece & 6 & 141 & Nemrut Dagi & Turkey & 4 \\
\hline 69 & Tenaghi Philippon & Greece & 6 & 142 & Üçağizli & Turkey & 1 \\
\hline 70 & Szeleta & Hungary & 1 & 143 & Howburn & UK & 3 \\
\hline 71 & Katla & Iceland & 4 & 144 & Kabazi II & Ukraine & 1 \\
\hline 72 & Tindfjallajškull & Iceland & 4 & 145 & Siuren I & Ukraine & 1 \\
\hline 73 & Kebara & Israel & 2 & 146 & Zaskalnaya V & Ukraine & 1 \\
\hline
\end{tabular}


comparison of statistical clusters or gradients in the geochemical data obtained from individual volcanic samples, is frequently made by eye, which can be quite subjective. In the remainder of this section we outline how these difficulties were addressed within RESET, starting with the development of more comprehensive proximal geochemical data.

\subsection{More robust proximal geochemical 'fingerprints'}

RESET set out to augment the major and trace element glass data for pyroclastic fall and flow deposits of key eruption events in Iceland, Germany, Italy, Greece and Turkey, in order to secure more robust data-arrays for proximal-distal tephra correlations. The most effective measurement tool for this purpose is grain-specific geochemical microanalysis of volcanic glass, obtained from both distal (ash) and proximal (juvenile magma) contexts. Major element compositions are widely reported from these materials, but it is now generally recognised that they are not always sufficiently diagnostic. As alluded to above, complications arise when highly evolved magmas, particularly those from a single volcano, are compositionally similar (e.g. Tomlinson et al., 2010; Pearce et al., 2014). Trace elements show greater variability than major elements because they are more strongly affected by differences in source composition and by sub-volcanic magmatic processes, such as fractional crystallisation and assimilation. For this reason, and where feasible, RESET implemented the routine measurement of major, minor and trace elements in the analysis of distal and proximal tephra samples investigated, using both electron probe micro-analysis (EPMA) and laser ablation inductively coupled plasma mass spectrometry (LA-ICP-MS). The accuracy of the sample analyses was established through regular calibration using glass reference materials, including the MPI-DING reference glasses (Jochum et al., 2006). Furthermore, because the geochemical variability within a population of tephra (glass) shards can be an additional diagnostic tool, RESET has consistently recorded the compositions of individual grains measured, and not population averages.

Using this approach, new geochemical data were obtained from a number of proximal settings to supplement those obtained by other research teams, for example from:

i. The Phlegrean Fields, Italy, from tephra layers dating to within the last $50 \mathrm{ka}$, including the Campanian Ignimbrite, Neapolitan Yellow Tuff, Pomici Principali and Tufi Biancastri (Tomlinson et al., 2012a);

ii. Sommo-Vesuvius, Italy, from tephra layers produced within the last $36 \mathrm{ka}$, including Pomici di Base, Verdoline, Mercato and Avellino (Tomlinson et al., 2015);

iii. The Colli Albani Magmatic Province, Italy (Cross et al., 2014);

iv. The Laacher See caldera in the Eifel region, Germany, source of the Laacher See Tephra, an important marker layer in parts of Europe dating to around 12.9 ka (Riede et al., 2011);

v. The Sólheimer Ignimbrite (Tomlinson, 2012c), one of the largest eruptions from the Katla caldera in Iceland, and considered by some to be the origin of the Vedde Ash, a widespread marker tephra throughout northern Europe and the NE Atlantic region dating to c. 12.1 ka (Birks et al., 1996);

vi. The Thorsmork Ignimbrite (Tomlinson et al., 2010), a caldera in southern Iceland from which the North Atlantic Ash Zone II tephra cluster, found in North Atlantic marine sediments, is assumed to originate (Lacasse and Garbe-Schönberg, 2001);

vii. Mt. Etna, the Aeolian Islands and the island of Ischia, thought to be the sources of several important tephra layers found in marine sequences in the Tyrrhenian Sea, as well as further afield (Albert et al., 2012, 2013; Tomlinson et al., 2014); viii. Pumice deposits on the Greek Islands of Nisyros (Tomlinson et al., 2012b) and Santorini (Tomlinson et al., 2015), the source of several tephras found in distal settings throughout the Aegean; and

ix. Western and central Anatolia (Tomlinson et al., 2015).

In addition, new investigations of the geochemical signatures of tephra layers preserved in a number of key terrestrial archives were undertaken, most notably in the Lago Grande di Monticchio lake sediment sequence in southern Italy. This site constitutes the most comprehensive tephra repository for the Mediterranean region, containing around 350 tephra layers spanning the last c. $133 \mathrm{ka}$ (Wulf et al., 2004, 2008). Not only are many of the widespread Mediterranean tephra markers, such as the Y-1 (sourced from Etna), Campanian Ignimbrite (Y-5), Neapolitan Yellow Tuff (C-2) and Monte Epomeo Green Tuff (Y-7) represented by thick deposits in this sequence, but many can be closely dated through a combination of varve, radiocarbon and sedimentation rate chronology. Collaborative links with RESET were established which led to the re-analysis of selected Lago Grande di Monticchio tephra marker layers (see Wulf et al., 2012; Tomlinson et al., 2012b, 2014).

The results of these investigations have reinforced the importance of maintaining a cautious approach when correlating tephra layers. Tomlinson et al. (2015) show how a more comprehensive understanding of proximal tectonic settings and the availability of trace element data can reveal subtle changes in magma chemistry, which allows more sensitive chemical discrimination than is the case when using major element ratios alone. The latter approach can differentiate volcanic products originating from different volcanic centres, but is less effective for discriminating materials derived from the same volcanic source. But the contribution to this volume by Wutke et al. (2015) reveals how, in some cases, this may equally apply where a robust suite of major, minor and trace element data are available, for this comprehensive approach failed to reveal significant differences between Lago Grande di Monticchio tephra layers derived from four successive eruptions of the Phlegrean Fields, deposited over a period of about 600 years. This can be a serious constraint, frustrating the effort to expand the tephra lattice, for it compromises precise correlation between records, especially in cases where the full complement of tephra layers is not preserved. Thus while the new data collated by RESET have helped to clarify a number of tephra correlations, they have also revealed limitations with the current chemical database that future research should address. We return to this in the final section of the paper.

\subsection{Expansion of tephra 'footprints'}

In parallel with the above-mentioned proximal investigations, other research conducted via RESET has focused on selected distal tephra layers that were known to be widely dispersed and to have relatively distinctive chemical signatures. The stratigraphic positions of a number of the investigated layers are shown in Fig. 5, relative to the Greenland isotope profile for the Last Glacial-Interglacial cycle, and using the age estimates of the tephras from Bronk Ramsey et al. (2015a).

Following careful geochemical characterisation procedures, outlined above, many of these tephras were detected in distal localities for the first time, helping to extend their geographical footprints. Examples, based on investigations of lake and mire sediment sequences, include new records of the Saksunarvatn Ash, derived from Iceland and dated to c. $10.3 \mathrm{ka}$, in NE Germany (Bramham-Law et al., 2013), of the Icelandic Vedde Ash as far south as North Italy, Switzerland and Slovenia (Lane et al., 2011a, 2011b, 2012a), and of the Laacher See Tephra, which was traced into SW Poland (Housley et al., 2013), while the Pomici Principali and 
Neapolitan Yellow Tuff volcanic ash layers, both derived from the Campanian volcanic complex, were traced further north as far as Slovenia (Lane et al., 2011b).

Analysis of marine cores conducted within the RESET project also served to underline their important potential as tephra archives within Mediterranean marine basins. The contribution in this volume by Matthews et al. (2015), for example, reveals that 28 discrete tephra layers are preserved within Adriatic core SA03-11, which spans the last c. $39 \mathrm{ka}$. Of these, 18 are non-visible cryptotephra layers, the majority of which can be matched to proximal deposits and/or tephras in the Monticchio archive. A number of the layers are derived from Campanian eruptions (including the Campanian Ignimbrite, recorded near the base of the sequence) and hence have very similar chemistries. However, most can be stratigraphically constrained, because they are bounded superpositionally by marker tephras with more distinctive chemical signatures, sourced from Vesuvius, the Aeolian Islands and Vulcano. A much longer record of tephra deposition is contained within core PRAD12, also from the Adriatic: this sequence extends back to $200 \mathrm{ka}$ and includes four volcanic eruptions recorded distally for the first time, the new data extending their corresponding eruption footprints by some $210 \mathrm{~km}$ further north (Bourne et al., 2010, 2015a). Investigation of marine core LC21, which extends over the last c. $166 \mathrm{ka}$, has also demonstrated the high potential for distal ash correlations in the Aegean region, for 17 tephras were recovered from this sequence ( 8 of which are cryptotephra layers), reflecting eruption plumes transported from Santorini, Kos, Yali, Nisyros, Pantelleria and Campania (Satow et al., 2015). Collectively, these studies are helping to clarify the fall footprints of important volcanic dispersal events and, when supported by robust geochemical characterisation data, provide a more secure basis for establishing marine-land correlations (e.g. Albert et al., 2012).

RESET also examined sediment sequences preserved in caves and rock shelters for the occurrence of cryptotephra deposits, in sites ranging in location from Iberia to the Levant (Lane et al., 2014). Of the 38 sites examined, around 30\% contained significant amounts of cryptotephra shards (see Davies et al., 2015), some containing several discrete layers in clear superposition. The record obtained from Theopetra Cave in Greece presented in this volume (Karkanas et al., 2015) exemplifies how three discrete cryptotephra layers were detected in the sequence and assigned to known eruption events, two from Pantelleria and one from Nisyros. These tephra layers provide bracketing ages for important archaeological layers in the sediment sequence. RESET also established the presence of distal European tephras, including the Campanian Ignimbrite, in North Africa for the first time, where they are preserved in archaeologically-important cave sequences (Lowe et al., 2012; Douka et al., 2014). Details of the latter discoveries, and of their potential for refining the chronology of stages in human evolution and cultural change in North Africa, are considered in the contribution to this special volume by Barton et al. (2015).

Less success was achieved with open-air archaeological sites confined to dry soils or sediments. A total of 34 Late Palaeolithic sites located on the European lowlands north of the Alps were investigated by RESET, but only around one fifth preserved cryptotephra layers. The contribution in this volume by Housley et al. (2015) reviews this collective evidence and considers the multiple factors that limit the chances of volcanic glass remaining preserved in dry-surface sites - the main ones possibly being taphonomic disturbance and pedogenic alteration.

\subsection{Building the tephra lattice}

The RESET tephra lattice was developed through a series of inter-connected activities. The first step was the construction of a project relational database, into which all the geochemical analytical data and related sample and site information could be compiled in standardised format. The new records have been collated with selected pre-existing data and with data-sets donated by collaborators, into a comprehensive database accessible on-line at https://c14.arch.ox.ac.uk/resetdb/db/php. The background to the construction of this database, the quality assurance criteria applied, guidance on how to navigate through the data, and the tools available for collating and analysing selected data, are all explained in the contribution to this volume by Bronk Ramsey et al. (2015b). Some of the data are temporarily embargoed, in cases where the evidence is deemed ambiguous or insufficienly robust, and interpretations equivocal. These will be released to open access in due course, as and when considered sufficiently robust.

The second step is the assignment of individual tephra layers to known volcanic sources and, where possible, specific eruption events, by matching clusters or trends in geochemical data distributions. The need for the application of numerical methods to test the degree of confidence attached to proposed statistical matches, such as discriminant function analysis (e.g. Kuehn and Foit, 2006; Brendryen et al., 2010), was recognised by the RESET team which worked towards developing a robust statistical tool for this purpose, employing kernel density analysis (Bronk Ramsey et al., 2015b). Unfortunately this tool did not reach maturity until towards the close of the RESET funding period, so was not systematically employed to test the matches reported in this special volume or in previously published RESET output (cited throughout this article). It is anticipated that this approach will be employed as a matter of routine in future studies, to test the strength of statistical matches between data sets.

The third step is that of establishing the precise ages of key tephra isochrons. The approach adopted by RESET depends on the reliability of the first two steps, for it is valid only where an individual tephra layer can be reliably traced between different sites, and where it truly represents a well-defined isochron. If such prerequisites can be shown to hold, then the collective chronological information obtained from all horizons in which the tephra is registered can be incorporated into age-modelling routines, to establish an overall best-estimate age for the tephra layer concerned, with specified error ranges. This procedure was adopted by RESET, using Bayesian statistical techniques to combine the probability distributions of all available age estimates for individual tephra isochrons (Bronk Ramsey et al., 2015a). This generates the best-estimate age range for each isochron, based on currently available information, but is subject to revision as new age estimates become available. The advantage of this isochron-dating approach is readily appreciated where the transfer of terrestrial radiocarbon age estimates to marine records is used to circumvent the problems of marine ${ }^{14} \mathrm{C}$ reservoir off-sets (e.g. Ikehara et al., 2011; Thornalley et al., 2011; Olsen et al., 2014).

The final step is to integrate all of the tephrostratigraphical data currently deposited in the RESET data-base to build the current tephra lattice, which is illustrated schematically in Fig. 6. Some of the more widespread and distinctive tephras constitute the major 'struts' of the lattice, as for example the Campanian Ignimbrite, which extends throughout the eastern Mediterranean and as far east as Montenegro and the River Don in Russia (Pyle et al., 2006; Morley and Woodward, 2011), and the Vedde Ash, the most widespread tephra in northern Europe within the period of interest (Lane et al., 2012b). Certain sites or records that contain distinctive tephra layers derived from two or more different volcanic centres act as important junctions in the lattice, linking more local tephra frameworks - for example Lago Grande di Monticchio and Lake Ohrid (Vogel et al., 2010). Fig. 6 also reveals how the 
tephrostratigraphic map of Europe, on current evidence, comprises two regional 'cells', reflecting north European and Mediterranean patterns of tephra circulation. RESET was able to link these two major cells when cryptotephra layers from Iceland (Vedde Ash) and Italy (Pomici Principali and the Neapolitan Yellow Tuff) were discovered in stratigraphic superposition in the same sediment sequence, in Lake Bled in the Julian Alps, Slovenia (Lane et al., 2011b). The importance of this development is considered below.

\section{Synchronising records using the tephra lattice}

Fig. 6 does not reflect the full array of tephrostratigraphical linkages represented in the RESET data-base, as that is difficult to portray graphically: the figure has been simplified for illustrative purposes. It is difficult, for example, to represent the numerous tephras preserved within the Monticchio sequence, of which only seven are included in the figure; similarly, only three of the 36 tephras reported from the PRAD1-2 sequence are indicated. Furthermore, a number of RESET sites are excluded from the figure altogether, as are some tephrostratigraphical links recently established independently by other teams, for example by Çaḡatay et al. (2015) for the eastern Mediterranean. Nevertheless what Fig. 6 does adequately convey is the potential that tephra isochrons offer for synchronising records at the continental scale: a chain of tephrostratigraphical tie-lines now connects the central Greenland ice sheet with much of Europe and the central and eastern Mediterranean, and extends into Africa, the Balkans and Russia. While some of the links have long been established and are relatively uncontested, others are helping to resolve what were previously less clear correlations or chronological relationships. A good example is to be found in the Lake Bled record. This contains (in cryptotephra form) both the Italian Pomici Principali (PP) and the Icelandic Vedde Ash (VA) tephra layers. Prior to this discovery, the precise age relationship between these two events was difficult to resolve because the error ranges (95\% confidence limits) on available age estimates overlapped considerably: 12,390-11,978 cal BP for the PP (Di Vito et al., 1999) compared with 12,171 $\pm 114 \mathrm{yr}$ b2k for the VA (Rasmussen et al., 2006). Crucially, however, both tephras are co-registered in the Lake Bled sequence, which demonstrates that the VA lies just below, and hence marginally predates, the PP (Lane et al., 2011b). In the light of this relationship, recalibration of the chronological information by Bronk Ramsey et al. (2015a) suggests mean ages of $11,999 \pm 52$ cal BP for the PP and $12,023 \pm 43 \mathrm{yr}$ BP for the VA - effectively contemporaneous, within the narrow errors. The importance of the Lake Bled discovery, therefore, is that all other records containing the PP, which on current evidence are mostly located far to the south of Lake Bled, can now be confidently aligned with the Greenland ice-core record at the VA horizon, even although the VA may not be represented in those sequences.

The recent discovery of the Neapolitan Yellow Tuff in the Meerfelder Maar sequence, in which the Laacher See Tephra and Vedde Ash are also preserved (Lane et al., submitted), is presently the only other record with tephra evidence that (a) links the southern and northern European tephrostratigraphical 'cells' reflected in Fig. 6, and (b) can be directly linked to the Greenland ice cores. If additional linkages like this could be established, it would allow more records to be aligned with the Greenland template using robust tie-points, and thus provide an independent means of establishing the degree to which AETs during the Last Glacial stage were synchronous at the continental scale. This, however, must await the identification of additional European tephras within the Greenland ice record, an issue we return to in the final section of this paper. Nevertheless, as Fig. 5 reveals, the current best-estimate ages for the tephra isochrons investigated by RESET suggest the majority of them to be critically positioned with respect to abrupt climatic events of the Last Glacial stage. For example, new results presented by Albert et al. (2015) in this special volume indicate the potential role of the Y3 tephra layer, deposited c. 2300 years after the onset of $\mathrm{H} 3$, as an important regional marker for assessing leads and lags in environmental responses to $\mathrm{H} 3$ throughout the central and eastern Mediterranean.

Assuming that the tephra isochrons represented in Fig. 5 are correctly assigned to specific eruption events, and that these events are also securely dated, then they should provide a series of robust markers for testing correlations or age models based on alternative methods, such as biostratigraphic or isotopic alignment. This approach was adopted, for example, by Bourne et al. (2010, 2015a) to test for synchroneity between sapropel-like sediment layers in the Adriatic and the established sapropel sequence of the eastern Mediterranean. Grant et al. (2012) also used two distinctive tephra isochrons, the Minoan tephra and the Campanian Ignimbrite, to test the reliability of an age model developed for core station LC21 in the eastern Mediterranean, and its alignment with the Soreq Cave speleothem record in Israel. Matthews et al. (2015) used optimised age estimates for several tephra isochrons to generate an age model for the SA03-11 sequence in the Adriatic, thus avoiding any reliance on marinebased radiocarbon dates, which may be distorted by marine reservoir effects. The degree to which these experiments have generated better-constrained age models for the sequences concerned awaits the scrutiny of future research. It should be noted, however, that even after the optimisation process (see Bronk Ramsey et al., 2015a), the current age estimates for the majority of the tephra markers represented in Fig. 5 have centennial-scale error ranges, constraining their chronological resolution.

The above examples focus on events in the Mediterranean region, where sediment sequences that span the Last Glacial stage are common. In much of northern Europe, by contrast, the tephra record tends to be confined to within the last $15 \mathrm{ka}$, since sediments did not begin to accumulate until after the demise of the last Eurasian ice sheet and thawing of the contemporaneous permafrost belt, which together covered much of the region. Within this limited time period, however, numerous tephra isochrons are available that are helping to improve the chronological resolution with which past environmental conditions can be reconstructed (e.g. Matthews et al., 2011; Brauer et al., 2014; MacLeod et al., 2014; Olsen et al., 2014). The results are increasingly revealing evidence for diachronous responses to climatic change during the Last Glacial-interglacial period, in cases where events can be compared with a sub-centennial temporal resolution. For example, using coregistered tephras common to several Alpine sites, Lane et al. (2012a) were able to show that re-colonisation of the northern Alps by thermophilous trees following the Last Glacial Maximum was delayed by several centuries compared with sites to the south of the range. An extraordinary degree of temporal resolution is afforded, however, where tephra isochrons and radiocarbon chronologies can be combined with varved records, as exemplified in a further study by Lane et al. (2013), which demonstrated that environmental response to marked climatic shift during the Younger Dryas (GS-1) interval was lagged by over a century in Norway compared with Germany. This type of evidence raises a question over environmental responses to climatic shifts in general: to what extent would many more examples of timetransgressive behaviour come to light, if earlier events could be investigated with a sub-centennial chronological resolution? The fact that we are presently not able to answer this question satisfactorily underlines the urgent need to improve the chronological resolution of geological dating methods, and justifies further investment in the refinement of the tephra lattice. 
One of the aims of RESET was to evaluate possible leads and lags in the timing of human responses to climatic forcing and other environmental impacts. This is one of the most challenging of the tasks that RESET confronted, because it requires the discrimination and precise dating of (a) the factors forcing change, (b) environmental responses to those forcing factors, and (c) human responses to both a and b, separately or in combination. What makes this exercise particularly difficult within the Palaeolithic period is the complexity of the archaeological record and the problems of dating the evidence securely, aspects that are developed in the contributions to this volume by Davies et al., d'Errico and Banks, and Hublin. RESET examined the potential role of tephra isochrons for resolving some of the chronological issues. At the broad millennial scale, some success was achieved by testing the hypothesis proposed by e.g. Fedele et al. (2008) and Golovanova et al. (2010), that marked changes in human dispersal and development during the Middle to Upper Paleolithic transition were attributable to a massive volcanic eruption and/or severe climatic deterioration during Heinrich Event 4 (H4). By tracing tephra of the Campanian Ignimbrite $(\mathrm{CI})$ eruption as an isochronous timeline between Palaeolithic sequences in southern and eastern Europe and one site in North Africa, it was possible to show that both Neanderthal and modern human populations survived the combined effects of the $\mathrm{CI}$, the largest caldera-forming eruption in Europe during the late Quaternary, and of the severely cold $\mathrm{H} 4$, the interval during which the CI erupted (Lowe et al., 2012). The evidence thus falsifies the proposal that the decline of the Neanderthals was caused by natural catastrophes, pointing instead to modern humans as the greater competitive threat to their survival.

In theory, other tephra isochrons, if detected within archaeological sequences, could provide a coherent basis for tracking changes in hominin dispersal, occupancy and cultural development over the course of the Palaeolithic. In practice, however, this goal is proving difficult to achieve for two important reasons. First, distinctive tephra markers have been found in relatively few Palaeolithic sequences so far, and these are geographically concentrated in the eastern Mediterranean and eastern inland Europe, so that larger-scale patterning in hominin behaviour is difficult to assess (Davies et al., 2015). Second, hominin cultural changes and colonisation patterns are inferred from lithic tool assemblages - so-called 'techno-complexes' or industries - which are often limited in geographical domain and short-lived in the archaeological record, while some are difficult to classify, appearing to be transitional between one industry and another. This highly complex background, as well as the problems of directly dating Palaeolithic records, is reviewed by Hublin (2015). This contribution makes it evident that much more tephrostratigraphical research will be required if this approach is to help unravel the Palaeolithic history of hominins in Eurasia.

Despite these difficulties, both d'Errico and Banks (2015) and Davies et al. (2015) see an important role for tephrochronology in advancing the study of Palaeolithic archaeology. The former authors explore how tephra evidence can be merged with other proxy evidence to establish best-fit chronological relationships between archaeological records, using the Campanian Ignimbrite as an exemplar. Davies et al. (2015) consider the potential of tephra evidence to explain some short-term or spatial differences in hominin distributions and activity, which could reflect differential environmental and ecological impacts of eruptions on sites located proximal to, or distal from, eruption centres. A further important application of tephra research in archaeology is a taphonomic one. Not all tephra layers occur as discrete, undisturbed layers, for some have clearly been dispersed through the sediments by downward percolation or sediment disturbance, especially in the case of small cryptotephra shards (e.g. Douka et al., 2014; Lane et al., 2014;
Barton et al., 2015). If tephra shards have been displaced in the sequence, so too might other materials, such as charcoal fragments and microfossils, which could have implications, for example, in the selection of samples for radiocarbon dating, or interpretation of the results.

\section{Future prospects}

The body of work generated by RESET highlights the potential that tephrostratigraphical studies offer for refining the chronology and synchronisation of late Quaternary records. The various outcomes of the project, summarised in earlier sections of this paper, constitute not only a legacy, but also a spring-board for further work, because it is clear that there is ample capacity for further development of the tephra lattice, with the promise of even finer chronological finesse in the future. One reason for this optimistic viewpoint is the recent proliferation of new records containing multiple, well-preserved tephra layers, including cryptotephras, which have been reported from, for example, the Tyrrhenian Sea (Morabito et al., 2014), the Ionian Sea (Insinga et al., 2014), the Black Sea (Cullen et al., 2014) and the Sea of Marmara (Çaḡatay et al., 2015). This suggests that cryptotephra layers are far more abundant and widely dispersed than previously assumed, while some marine repositories, in places where sedimentation has been continuous and undisturbed, preserve rich, stratigraphicallyordered archives of past volcanic activity. The evidence also points to the possibility that some distal tephra deposits record episodes of volcanic activity that are not reflected in proximal records. Furthermore, some tephra layers identified during RESET investigations have not yet been adequately characterised or added to the lattice; additional data from these layers may further augment the lattice. For example, a tephra with a geochemical signature that suggests an origin in the Azores was discovered at the Moroccan cave site of Taforalt, while a tephra of probable Anatolian origin was detected in the sediments of the Egyptian cave site of Sodmein (Barton et al., 2015). If traced to specific eruptions of known age, examples such as these would not only provide additional links in the lattice, but could extend the chain of tephra connections to new areas.

On the theme of developing the lattice in the future, some of the issues that require further investigation include the following. First, the majority of tephras in southern Europe were dispersed eastwards, and RESET was unable to detect tephras in the western part of the Mediterranean or in the Iberian Peninsula (Hardiman, 2012). This could be because of choice of site (very few records in this region were examined within RESET), or because cryptotephras are present in extremely low concentrations, or because very little, if any, eruptive material was transported to this region. A more thorough investigation of sequences in western Europe is therefore required. Second, Fig. 5 shows that there is a notable disparity in the number of tephra isochrons recognised for the post-50 ka period compared with the earlier part of the Last Glacial stage. This probably reflects sampling issues, for some of the sequences investigated by RESET did not extend beyond $50 \mathrm{ka} \mathrm{BP}$, while in general there has been a greater focus of interest on the younger period. Older tephras are, however, increasingly being detected, especially in Mediterranean marine records (e.g. Bourne et al., 2010, 2015a; Insinga et al., 2014; Satow et al., 2015), while the Lago Grande di Monticchio record suggests that many more could potentially be traced to both marine and terrestrial records (Wulf et al., 2004), a topic also worthy of further exploration. A third issue concerns the nature and stratigraphic context of distal tephra layers, for not all ash deposits form discrete, stratigraphically constrained layers; some are clearly spread through a wide stratigraphic interval, to the extent that it is often unclear which horizon 
represents the time of the eruption event, a complication adding to chronological uncertainty.

In essence, no age estimate is free from uncertainty, which is why RESET has preferred the practice of deriving optimised ages using all of the chronological information available for individual tephra isochrons (Bronk Ramsey et al., 2015a). The expectation is that the precision of these age estimates, and of the lattice as a whole, will progressively be refined as new data is forthcoming. An ideal way to test the ages assigned to these tephra isochrons would be if their equivalents could be detected in the Greenland ice-core records, for these would have independently-determined GICC05 ages. An extensive programme of research conducted over the last decade or so has revealed evidence of numerous cryptotephra layers in the Greenland ice cores (e.g. Abbott and Davies, 2012). In this volume, for example, Bourne et al. (2015b) report on the discovery of 99 tephra layers in the Greenland ice dating to between 45 and $25 \mathrm{ka} \mathrm{b2k}$. Unfortunately, none of these are sourced from southern European volcanoes, but are nearly all derived from Iceland, while relatively few can be assigned to specific eruption events. Nevertheless, they hold considerable promise for establishing robust tie-lines between North Atlantic marine deposits and the Greenland ice-core records (Griggs et al., 2014), and the possibility cannot be discounted that this may eventually lead to the discovery of further overlaps between the footprints of Icelandic and south European ash dispersals, as in the cases of Lake Bled and Meerfelder Maar.

It is also worth reflecting on the global context, for distal tephrostratigraphical frameworks are now being developed for many parts of the world (see Lowe, 2008, 2011), for example in New Zealand (Shane, 2005), southern Patagonia (Wastegård et al., 2013), Anatolia (Tryon et al., 2009) and sub-arctic Russia (van den Bogaard et al., 2013). The prospect of linking these regional lattices at the global scale at some stage is not merely fanciful, for distal equivalents of an Alaska-sourced tephra have been detected in the North Atlantic, northern Europe and the Greenland ice sheet, representing a volcanic footprint that extends over at least $7000 \mathrm{~km}$ (Jensen et al., 2014), while tephra originating from volcanoes in the Andes has been discovered in Antarctic ice cores (e.g. Narcisi et al., 2005). It is therefore vitally important to continue to develop regional tephra lattices, and to explore ways of further refining the methods used to detect, chemically fingerprint and date distal ash layers, for they clearly have the propensity to link stratigraphic sequences on an inter-continental scale. In recognition of this potential, steps are being taken to foster a global network of scientists engaged with late Quaternary tephrochronology, to explore this larger-scale perspective, notably through the INQUA-supported INTAV initiative (International Focus Group on Tephrochronology and Volcanism: http://www.arch.ox.ac.uk/intav/INQUA-INTAV.html) and its core project INTREPID ('Enhancing tephrochronology as a global research tool through improved fingerprinting and correlation techniques and uncertainty modelling': http://www.inqua.org/ publications_QuatPersp.html).

So far as late Quaternary tephra research in Europe is concerned, this has clearly mushroomed in recent years, even within the short interval over which RESET was funded, with an increasing number of scientists generating large quantities of geochemical data, only a proportion of which resides in the RESET database. This raises questions about the systematic and efficient storage, classification, synthesis and custody of this growing volume of data in the future, and whether it perhaps requires a larger collaborative consortium to co-ordinate the effort required, not only to preserve the information for long-term posterity, but also to gain the maximum benefit that tephrostratigraphic research can offer. The benefits would far outweigh the cost.

\section{Acknowledgements}

RESET was funded through Consortium Grants awarded by the Natural Environment Research Council, UK, to a collaborating team drawn from four institutions: Royal Holloway University of London (grant reference NE/E015905/1), the Natural History Museum, London (NE/E015913/1), Oxford University (NE/E015670/1) and the University of Southampton, including the National Oceanography Centre (NE/01531X/1). The authors also wish to record their deep gratitude to four members of the scientific community who formed a consultative advisory panel during the lifetime of the RESET project: Professor Barbara Wohlfarth (Stockholm University), Professor Jørgen Peder Steffensen (Niels Bohr Institute, Copenhagen), Dr. Martin Street (Romisch-Germanisches Zentralmuseum, Neuwied) and Professor Clive Oppenheimer (Cambridge University). They provided excellent advice at key stages of the work, which we greatly valued. We also thank Jenny Kynaston (Geography Department, Royal Holloway) for construction of several of the figures in this paper, and Debbie Barrett (Elsevier) and Colin Murray Wallace (Editor-in-Chief, QSR) for their considerable assistance in the production of this special volume.

\section{Appendix 1. The RESET Research team}

Workpackage (WP) leaders

John Lowe (Royal Holloway University of London [RHUL]) overall project co-ordinator.

Chris Stringer (Natural History Museum, London [NHM]), William Davies (Southampton University), co-ordinators WP 1.

Nick Barton, Mark Pollard (Inst Archaeol \& RLAHA, Oxford University) co-ordinators WP2.

Clive Gamble (RHUL, now at Southampton University), coordinator WP3.

Martin Menzies (RHUL), co-ordinator WP4.

Eelco Rohling, Andrew Roberts (Southampton University \& NOCS, both now at ANU), co-ordinators WP5.

Simon Blockley (RHUL), co-ordinator WP6.

Chris Bronk Ramsey (RLAHA, Oxford University) co-ordinator WP7.

\section{Appointed staff}

Victoria Cullen (RLAHA, Oxford) - Technician, WP1, 2, 3 and 6. Katharine Grant (Southampton University \& NOCS, now at ANU) - PGRA, WP-5.

Rupert Housley (Geography, RHUL) - Project Manager \& PDRA, WP-3.

Christine Lane (RLAHA, Oxford, now at Manchester University) - formerly PDRA, WP1, 2 \& 6.

Mark Lewis (NHM) - Technician, WP-1.

Alison MacLeod (Geography, RHUL) - formerly PDRA, WP-3.

Emma Tomlinson (Earth Science, RHUL, now Trinity College Dublin) - formerly PDRA, WP-4.

Dustin White (Institute of Archaeology, Oxford \& Southampton Universities) - PDRA, WP-1 \& WP-2.

Tied \& Associated postgraduate students

Paul Albert (Earth Sciences, RHUL; PhD studentship, now at Swansea University) - WP-4.

Mark Hardiman (Geography, RHUL; NERC PhD studentship, now at Plymouth University) - WP-6. 
Sharen Lee (RLAHA, Oxford; NERC studentship) - WP-7. Anna Oh (RLAHA, Oxford) - WP-2.

Christopher Satow (Geography, RHUL \& NOCS; NERC PhD studentship, now at Kingston University, UK) - WP-5.

Joanna K. Cross (Earth Sciences, RHUL; PhD studentship) - WP-4. Cassian Bramham Law (RLAHA, Oxford; NERC PhD studentship) - WP-3.

Anna Todman (Earth Sciences, RHUL; MSc studentship) - WP-4.

Associated researchers

Anna Bourne (Geography, RHUL, now Swansea University) associated with WP-5.

Ian Matthews (Geography, RHUL) - associated with WP-5 \& WP-6.

Wolfgang Müller (Earth Sciences, RHUL) - associated with WP4.

Victoria Smith (RLAHA, Oxford) - associated with WP-4 \& WP-6. Sabine Wulf (GFZ German Research Centre for Geosciences, Potsdam) - associated with WP-4 \& WP-6.

Inst. Arch. - Institute of Archaeology; RLAHA - Research Laboratory of Archaeology \& the History of Art; NOCS - National Oceanography Centre, Southampton; ANU - Australian National University.

\section{Appendix 2. RESET Collaborators by work package}

The following individuals arranged access to selected field sites and sampling profiles, provided supporting data and/or assisted with sampling procedures, thereby greatly assisting the RESET team in meeting its strategic goals.

\section{WP-1: Neanderthals and modern humans in Europe}

Tincova, Coşava II and Romanesti-Dumbravita I - M. Anghelinu (Department of History and Letters, University of Valahia Târgoviște, Romania); Grub/Kranawetberg - W. Antl-Weiser (Natural History Museum Vienna, Austria); Kebara - O. Bar-Yosef (Department of Anthropology, Peabody Museum, Harvard University, USA); Tabula Traiana - D. Borić (Cardiff School of History, Ancient History, Archaeology and Religion, Cardiff University, UK); Riparo L'Oscurusciuto and Grotta di Santa Croce - P. Boscato and A. Ronchitelli (Dipartimento di Scienze Ambientali, U.R. Ecologia Preistorica, Università di Siena, Italy); Siuren I, Kabazi II, Zaskalnaya $V$ and Karabai II - V. Chabai and A. Veselsky (Crimean Branch of the Institute of Archaeology, National Ukrainian Academy of Sciences, Simferopol, Ukraine) and Th. Uthmeier (Institute of Prehistoric Archaeology, University of Erlangen, Germany); Franchthi - W. Farrand (University of Michigan, USA); Shpella e Hurdhës, Shpella e Blaz and Shpella e Zezë - I. Gjipali and R. Ruka (Institute of Archaeology, Tirana, Albania); Üçagizli I - E. Güleç (Antropoloji Bölümü, Ankara Üniversitesi, Turkey); Mujina pećina and Velika pećina in Kličevica - I. Karavanić (Department of Archaeology, University of Zagreb, Croatia); Lakonis I, Klissoura 1 and Theopetra P. Karkanas (Ephoreia of Palaeoanthropology-Speleology of Southern Greece, Athens, Greece); Azokh - T. King (Yerevan Institute of Man, Armenia); Romualdova pećina - D. Komšo (Archaeological Museum of Istria, Croatia); Klissoura 1 - M. Koumouzelis (Ephoreia of Palaeoanthropology-Speleology of Southern Greece, Athens, Greece); Theopetra - N. Kyparissi (Ephoreia of Palaeoanthropology-Speleology of Southern Greece, Athens, Greece); Szeleta - G. Lengyel (Department of Prehistory and

\footnotetext{
$\dagger$ Deceased.
}

Archaeology, University of Miskolc, Hungary) and Z. Mester (Institute of Archaeological Sciences, Eötvös Loránd University, Budapest, Hungary); Vedrovice V, Moravsky Krumlov IV and Kůlna P. Neruda (ústav Anthropos, Moravské zemské museum, Brno, Czech Republic); Beregovo, Molodova $V$ and Kostenki 14 - P. Nigst (Department of Archaeology, University of Cambridge, UK) and P. Haesaerts (Royal Belgian Institute of Natural Sciences, Brussels, Belgium); Lakonis $I-$ E. Panagopoulou (Ephoreia of Palaeoanthropology-Speleology of Southern Greece, Athens, Greece); Golema Pesht - L. Shalamanov-Korobar and I. Tolevski (National Institution Museum of Macedonia, Skopje, Republic of Macedonia); Kostenki 14 - A. Sinitsyn (Institute for the History of Material Culture, Russian Academy of Sciences, Saint Petersburg, Russia); Kozarnika and Redaka II - N. Sirakov and A. Guadelli (National Institute of Archaeology and Museum of Bulgarian Academy of Sciences, Sofia, Bulgaria) and J-L. Guadelli and C. Ferrier (Centre National de la Recherche Scientifique, Université Bordeaux 1, France); Ondratice I-Zelec and Bohunice-Brno 2002 - P. Skrdla (Institute of Archaeology, Academy of Sciences of the Czech Republic, Brno, Czech Republic); Grotte Mandrin - L. Slimak (CNRS, TRACES, Université de Toulouse le Mirail, France); L'Arbreda - N. Soler and J. Soler (Institut de Recerca Històrica, Universitat de Girona, Spain); Les Cotté - M. Soressi (Institut national de recherches archéologiques preventives, Saint Cyr-en-Val, France); Bondi and Undo - N. Tushabramishvilii (Georgian National Museum, Tbilisi, Republic of Georgia); Cueva Antón - J. Zilhão (Departament de Prehistòria, Universitat de Barcelona, Spain) and D. Angelucci (Dipartimento di Lettere e Filosofia, Università degli Studi di Trento, Italy). Laboratory processing for WP-1 and WP-2 was conducted by P. Albert, C. Bramham Law, V.L. Cullen, P. Lincoln, R. Staff and K. Flower.

WP-2: Impact of AETs on early modern human populations in North Africa

Aïn El-Guettar and Oued El Akarit - N. Aouadi-Abdeljaouad (National Museum of Raqqada, Kairouan, Tunisia) and L. Belhouchet (Institut National du Patrimoine, Tunis, Tunisia); Haua Fteah G. Barker (McDonald Institute for Archaeological Research, University of Cambridge, UK); Taforalt, Dar es-Soltan I and Rhafas - A. Bouzouggar (Institut National des Sciences de l'Archéologie et du Patrimoine, Rabat, Morocco); Sodmein - P. Van Peer (Prehistoric Archaeology Unit, Katholieke Universiteit Leuven, Belgium) and K. Kindermann (Institute of Prehistoric Archaeology, University of Cologne, Germany).

\section{WP-3: Re-populating Europe after the Last Glacial Stage}

Oldendorf/Schünsmoor - K. Gerken (Neustadt, Germany) and $\mathbf{H}$. Niemann (Breman, Germany); Howburn - R. Tipping (School of Biological and Environmental Sciences, University of Stirling, UK), A. Saville (National Museums Scotland, Edinburgh) and T. Ward (Biggar Archaeology Group, Biggar, UK); Ahrenshöft LA58D - I. Clausen and M.-J. Weber (Centre for Baltic and Scandinavian Archaeology, Schloss Gottorf, Schleswig-Holstein, Germany); Grabow $15-\mathbf{K}$. Kaiser (Faculty of Geography, University of Marburg, Germany), J.F. Torksdorf (Institute of Prehistoric Archaeology, University of Marburg, Germany), F. Turner (Institute of Geobotany, Leibniz University of Hannover, Germany) and S. Veil (State Museum of Lower Saxony, Germany); Lille Slotseng - N. Nygaard (Department of Geology, University of Copenhagen, Denmark) and S.D.F. Pyne-O'Donnell (Department of Earth Science, University of Bergen, Norway); Węgliny - M. Masojć (University of Wrocław, Institute of Archaeology, Wrocław, Poland), D. Nalepka and A. Jurochnik (W. Szafer Institute of Botany, PAS, Kraków, Poland); 
Mirkowice 33 - J. Kabaciński (Institute of Archaeology and Ethnology, PAS, Poznań, Poland); Dourges - P. Antoine (UMR CNRS 8591 - Laboratoire de Géographie Physique - France); Étiolles - M. Olive and M. Christensen (UMR CNRS 7041 - Université de Paris 1 - France); Pincevent - P. Bodu, G. Debout and M. Orliac (UMR CNRS 7041 - Université de Paris 1 - France); Arendonk De Liereman and Lommel Maatheide - M. De Bie and M. Van Gils (Flemish Heritage Institute, Brussels, Belgium); Opgrimbie - E. Paulissen (K.U. Leuven, Belgium); Alzette - L. Brou (Section Préhistoire, Musée national d'histoire et d'art, Luxembourg); Neuchâtel - D. Leesch, P. Hadorn and N. Thew (Office et musée cantonal d'archéologie, Neuchâtel, Switzerland); Ahrenshöft LA58D, Oldendorf/ Schünsmoor, Tolk - F. Riede (Institut for Antropologi, Arkæologi og Lingvistik, University of Aarhus, Denmark); Wesseling-Eichholz- M. Heinen (Institut für Ur-und Frühgeschichte, Köln, Germany); Breitenbach - o. Joris (MONREPOS Archäologisches Forschungszentrum und Museum für menschliche Verhaltensevolution, Neuwied, Germany); Lengefeld-Bad Kösen - J. Richter (Institut für Ur-und Frühgeschichte, Köln, Germany) and Th. Uthmeier (Institut für Ur-und Frühgeschichte, Erlangen, Germany); Reichwalde - M. Knipping, H.-P. Stika and M. Friedrich (Universität Hohenheim, Institut für Botanik und Botanischer Garten, Stuttgart, Germany); Hohle-Fels - N. Conard and M. Malina (Universität Tübingen, Abteilung Ältere Urgeschichte und Quartärökologie, Tübingen, Germany); Hohlenstein-Stadel - C.-J. Kind and Th. Beutelspacher (Regierungspräsidium Stuttgart, Landesamt für Denkmalpflege, Esslingen a.N., Germany); Hasselø and Lundby Mose - M. F. Mortensen (The National Museum of Denmark, Copenhagen, Denmark); Łęgoń 5, Olbrachcice 8, Siedlnica $17 \& 17 \mathrm{~A}$ and Strumienno $1-\mathbf{J}$. M. Burdukiewicz (University of Wrocław, Institute of Archaeology, Wrocław, Poland) and A. Szynkiewicz (University of Wrocław, Institute of Geological Sciences, Wrocław, Poland); Dzierysław 35 - M. Połtowicz-Bobak and D. Bobak (University of Rzeszów, Institute of Archaeology, Rzeszów, Poland); Sowin 7 - A. Wiśniewski (University of Wrocław, Institute of Archaeology, Wrocław, Poland); Ćmielów 95/Maty Gowroniec and Podgrodzie 16/Lysowody 119 - M. Przeździecki (University of Warsaw, Institute of Archaeology, Warsaw, Poland); Hłomcza - P. Valde-Nowak (Jagiellonian University, Archaeological Institute, Kraków, Poland) and A. Muzyczuk (Krosno Museum, Poland). Laboratory processing was conducted by C. Bramham Law, V. L. Cullen, L. Davies, P. Lincoln and A. MacLeod. Additional field assistance provided by P. Morgan (Department of Geography, University of Southampton, UK).

\section{WP-4: Geochemical fingerprinting of tephras}

Erkan Aydar \& Evren Çubukçu, Hacettepe University, Ankara (Turkey); Richard Brown, University of Durham (Ischia); Mauro Coltelli \& Deborah Lo Castro, INGV, Catania (Etna); Raffaello Cioni, Universita' di Cagliari, Italy (Vesuvius); Rosanna DeRosa \& Paola Donato Univ Calabria, Italy (Tyrrhenian Coast); Alessio Di Roberto, INGV, Pisa (Tyrrhenian Sea); Ralf Gertisser, University of Keele (Azores); Guido Giordano, Roma Tre, Rome (Colli Albani, Aeolian Islands); Mike Branney \& Nina Jordan, University of Leicester (Pantelleria); Jörg Keller Univ Freiburg Germany (Ionian Sea, Aeolian Islands); Helen Kinvig, Jo Gottsman \& Jon Blundy, University Bristol (Nisyros); Michael Marani, ISMAR, CNR Bologna (Tyrrhenian Sea); Giovanni Orsi, Lucia Civetta, Ilenia Arienzo, Antonio Carandente, INGV Naples (Vesuvius, Campi Flegrei, Ischia, Pantelleria); Mauro Rosi \& Giovanni Zanchetta, University of Pisa (Campi Flegrei, Vesuvius, Aeolian Islands); Ioan Seghedi, Institute of Geodynamics, Bucharest, \& Alex Szakacs, Sapientia University, Romania (Ciomadul); Roberto Sulpizio University of Bari (Campi
Flegrei); Thor Thordarson, University of Edinburgh \& Reykjavik (Iceland); Sabine Wulf, Potsdam (Campanian).

WP-5: AETs and tephras in marine sediment cores

Fabio Trincardi and Luigi Vigliotti (ISMAR, Bologna); Alesssandra Asioli (Istituto di Geoscienze e Georisorse del C.N.R, Padova); Andrea Piva (SPES, Sedimentology, Petrography and Stratigraphy); Sabine Wulf (GFZ, Potsdam).

WP-6: AETs and tephras in continental records

M. Andrič (Institute of Archaeology, Scientific Research Centre of the Slovenian Academy of Sciences and Arts); A. Brauer and $\mathbf{S}$. Wulf (GFZ Potsdam); P. de Klerk (Staatliches Museum für Naturkunde Karlsruhe); M-L. Filippi (Museo Tridentino di Scienze Naturali, Department of Geology); W. Finsinger (Centre for Bioarchaeology and Ecology, University of Montpellier); L. Galović (Croatian Geological Survey); T. Jones (Lancaster Environment Centre, Lancaster University); A. Lotter (Institute of Environmental Biology, Palaeoecology, Laboratory of Palaeobotany and Palynology, University of Utrecht); U. Müller and J. Pross (Institute of Geosciences, Goethe University Frankfurt); J. Mangerud, Ø. Lohne and S. Pyne-O'Donnell (Department of Earth Sciences \& Bjerknes Centre for Climate Research, University of Bergen); S. Markovic (Faculty of Sciences, University of Novi Sad); I. Matthews (Centre for Quaternary Research, Royal Holloway University of London); R. Pini and C. Ravazzi (Istituto per la Dinamica dei Processi Ambientali, Laboratorio di Palinologia e Paleoecologia, Milan); F. Riede (Institut for Antropologi, Arkæologi og Lingvistik, Aarhus Universitet); M. TheuerKauf (Institute for Geography and Geology, University of Greifswald); C. Tzedakis and V. Margari (Department of Geography University College London); D. Veres (Laboratoire de Glaciologie et Geophysique de l'Environnement/Romanian Academy, Institute of Speleology "Emil Racovita"); S. Wastegård (Department of Physical Geography and Quaternary Geology. Stockholm University); J. E. Ortiz, T. Torres and A. Díaz-Bautista (Laboratory of Biomolecular Stratigraphy, E.T.S.I. Minas de Madrid, Madrid); A. Moreno and B. Valero-Garcés (Pyrenean Institute of Ecology, Zaragoza); S. Lowick (University of Bern); Lusia Ottolini (CNR-Istituto di Geoscienze e Georisorse, Pavia).

Laboratory processing was conducted by V. L. Cullen.

\section{References}

Abbott, P.M., Davies, S.M., 2012. Volcanism and the Greenland ice cores: the tephra record. Earth Sci. Rev. 115, 173-191.

Albert, P.G., Tomlinson, E.L., Smith, V.C., Di Roberto, A., Todman, A., Rosi, M., Marani, M., Muller, W., Menzies, M.A., 2012. Marine-continental tephra correlations: Volcanic glass geochemistry from the Marsili Basin and the Aeolian Islands, Southern Tyrrhenian Sea, Italy. J. Volcanol. Geotherm. Res. 229-230, 74-94.

Albert, P.G., Tomlinson, E.L., Lane, C.S., Wulf, S., Smith, V.C., Coltelli, M., Keller, J., Lo Castro, D., Manning, C.J., Müller, W., Menzies, M.A., 2013. Late Glacial explosive activity on Mount Etna: implications for proximal-distal tephra correlations and the synchronisation of Mediterranean archives. J. Volcanol. Geotherm. Res. 265 9-26.

Albert, P.G., Hardiman, M., Keller, J., Tomlinson, E.L., Smith, V.C., Bourne, A.J., Wulf, S., Zanchetta, G., Sulpizio, R., Müller, U.C., Pross, J., Ottolini, L., Matthews, I.P., Blockley, S.P.E., Menzies, M.A., 2015. Revisiting the Y-3 tephrostratigraphic marker: a new diagnostic glass geochemistry, age estimate, and details on its climatostratigraphical context. Quat. Sci. Rev. 118, 105-121.

Alloway, B.V., Lowe, D.J., Larsen, G., Shane, P.A.R., Westgate, J.A., 2013. Tephrochronology. In: Elias, S.A. (Ed.), Encyclopedia of Quaternary Science, second ed., vol. 4, pp. 277-304.

Austin, W.E.N., Hibbert, F.D., 2012. Tracing time in the ocean: a brief review of chronological constraints (60-8 kyr) on North Atlantic marine event-based stratigraphies. Quat. Sci. Rev. 36, 28-37.

Barton, R.N.E., Lane, C.S., Albert, P.G., White, D., Collcutt, S.N., Bouzouggar, A., Ditchfield, P., Farr, L., Oh, A., Ottolini, L., Smith, V.C., Van Peer, P., Kindermann, K., 2015. The role of cryptotephra in refining the chronology of Late Pleistocene 
human evolution and cultural change in North Africa. Quat. Sci. Rev. 118, 151-169.

Bartov, Y., Goldstein, S.L., Stein, M., Enzel, Y., 2003. Catastrophic arid episodes in the Eastern Mediterranean linked with the North Atlantic Heinrich events. Geology 31, 439-442.

Birks, H.H., Gulliksen, S., Haflidason, H., Mangerud, J., Possnert, G., 1996. New radiocarbon dates for the Vedde ash and the Saksunarvatn ash from western Norway. Quat. Res. 45, 119-127.

Blaauw, M., 2012. Out of tune: the dangers of aligning proxy archives. Quat. Sci. Rev. $36,38-49$

Blockley, S.P.E., Pinhasi, R., 2011. A revised chronology for the adoption of agriculture in the Southern Levant and the role of Lateglacial climatic change. Quat. Sci. Rev. 30, 98-108.

Blockley, S.P.E., Pyne-O'Donnell, S.D.F., Lowe, J.J., Matthews, I.P., Stone, A., Pollard, A.M., Turney, C.S.M., Molyneux, E.G., 2005. A new and less destructive laboratory procedure for the physical separation of distal glass tephra shards from sediments. Quat. Sci. Rev. 24, 1952-1960.

Blockley, S.P.E., Blockley, S.M., Donahue, R.E., Lane, C.S., Lowe, J.J., Pollard, A.M., 2006. The chronology of abrupt climate change and Late Upper Palaeolithic human adaptation in Europe. J. Quat. Sci. 21, 575-584.

Blockley, S.P.E., Bronk Ramsey, C., Lane, C.S., Lotter, A.F., 2008. Improved age modelling approaches as exemplified by the revised chronology for the Central European varved Lake Soppensee. Quat. Sci. Rev. 27, 61-71.

Blockley, S.P., Lane, C.S., Hardiman, M., Rasmussen, S.O., Seierstad, I.K., Steffensen, J.P., Svensson, A., Lotter, A.F., Turney, C.S.M., Bronk Ramsey, C., INTIMATE Members, 2012. Synchronisation of palaeoenvironmental records over the last 60,000 years, and an extended INTIMATE event stratigraphy to 48,000 b2k. Quat. Sci. Rev. 36, 2-10.

Blockley, S.P.E., Bourne, A.J., Brauer, A., Davies, S.M., Harding, P.R., Lane, C.S., MacLeod, A., Matthews, I.P., Pyne-O-Donnell, S.D.F., Rasmussen, S.O., Wulf, S., Zanchetta, G., 2014. Tephrochronology and the extended intimate (integration of ice-core, marine and terrestrial records) event stratigraphy (8-128 ka b2k). Quat. Sci. Rev. 106, 88-100.

Blome, M.W., Cohen, A.S., Tryon, C.A., Brooks, A.S., Russell, J., 2012. The environmental context for the origins of modern human diversity: a synthesis of regional variability in African climate 150,000-30,000 years ago. J. Hum. Evol. $62,563-592$.

Bourne, A., Lowe, J.J., Trincardi, F., Asioli, A., Blockley, S., Wulf, S., Matthews, I.P., Piva, A., Vigliotti, L., 2010. Tephrostratigraphical record of the last c. 105,000 years obtained from core PRAD 1-2 in the Central Adriatic Sea. Quat. Sci. Rev. 29, 3079-3094.

Bourne, A.J., Cook, E., Abbott, P.M., Seierstad, I.K., Steffensen, J.P., Svensson, A., Fischer, H., Shüpbach, S., Davies, S.M., 2015b. A tephra lattice for Greenland and a reconstruction of volcanic events spanning 25-45 ka b2k. Quat. Sci. Rev. 118, $122-141$.

Bourne, A.J., Albert, P.G., Matthews, I.P., Trincardi, F., Wulf, S., Asioli, A., Blockley, S.P., Keller, J., Lowe, J.J., 2015a. Tephrochronology of core PRAD 1-2 in the Adriatic Sea: insights into Italian explosive volcanism for the period 200-80 ka. Quat. Sci. Rev. 16, 28-43.

Bramham-Law, C.W.F., Theuerkauf, M., Lane, C.S., Mangerud, J., 2013. New findings regarding the Saksunarvatn Ash in Germany. J. Quat. Sci. 28, 248-257.

Brauer, A., Hajdas, I., Blockley, S.P.E., Bronk Ramsey, C., Christl, M., Ivy-Ochs, S., Moseley, G.E., Nowaczyk, N.N., Rasmussen, S.E., Roberts, H.M., Spötl, C., Staff, R.A., Svensson, A., 2014. The importance of independent chronology in integrating records of past climate change for the 60-8 ka INTIMATE time interval. Quat. Sci. Rev. 106, 47-66.

Brendryen, J., Haflidason, H., Sejrup, H.P., 2010. Norwegian Sea tephrostratigraphy of marine isotope stages 4 and 5: prospects and problems for tephrochronology in the North Atlantic region. Quat. Sci. Rev. 29, 847-864.

Bronk Ramsey, C., Albert, P., Blockley, S.P.E., Hardiman, M., Housley, R.A., Lane, C.S., Lee, S., Matthews, I.P., Smith, V.C., Lowe, J.J., 2015a. Improved age estimates for important Late Quaternary European tephra horizons in the RESET lattice. Quat. Sci. Rev. 118, 18-32.

Bronk Ramsey, C., Housley, R.A., Lane, C.S., Smith, V.C., Pollard, A.M., 2015b. The RESET tephra database and associated analytical tools. Quat. Sci. Rev. 118, 33-47.

Çaḡatay, M.N., Wulf, S., Sancar, Ü., Özmaral, A., Vidal, L., Henry, P., Appelt, O., Gasperini, L., 2015. The tephra record from the Sea of Marmara for the last ca. $70 \mathrm{ka}$ and its palaeoceanographic implications. Mar. Geol. 361, 96-110.

Carto, S.L., Weaver, A.J., Hetherington, R., et al., 2009. Out of Africa and into an ice age: on the role of global climate change in the late Pleistocene migration of early modern humans out of Africa. J. Hum. Evol. 56, 139-151.

Clement, A.C., Peterson, L.C., 2008. Mechanisms of abrupt climate change of the Last Glacial period. Rev. Geophys. 46 http://dx.doi.org/10.1029/2006RG000204.

Costa, A., Folch, A., Macedonio, G., Giaccio, B., Isaia, R., Smith, V.C., 2012. Quantifying volcanic ash dispersal and impact of the Campanian Ignimbrite super-eruption. Geophys. Res. Lett. 39 (10) http://dx.doi.org/10.1029/2012GL051605.

Cross, J.K., Tomlinson, E.L., Giordano, G., Smith, V.C., De Benedetti, A.A., Roberge, J., Manning, C.J., Wulf, S., Menzies, M.A., 2014. High level triggers for explosive mafic volcanism: Albano Maar, Italy. Lithos 190-191, 137-153.

Cullen, V.L., Smith, V.C., Arz, H.W., 2014. The detailed tephrostratigraphy of a core from the south-east Black Sea spanning the last 60 ka. J. Quat. Sci. 29, 675-690.
Davies, S.M., Branch, N.P., Lowe, J.J., Turney, C.S.M., 2002. Towards a European tephrochronological framework for the Last Termination and early Holocene. Philos. Trans. R. Soc. Lond. Ser. A 360, 767-802.

Davies, W., White, D., Lewis, M., Stringer, C., 2015. Evaluating the transitional mosaic: frameworks of change from Neanderthals to Homo sapiens in eastern Europe. Quat. Sci. Rev. 118, 211-242.

De Vivo, B., Rolandi, G., Gans, P.B., Calvert, A., Bohrson, W.A., Spera, F.J., Belkin, H.E., 2001. New constraints on the pyroclastic eruptive history of the Campanian volcanic Plain (Italy). Miner. Petrol. 73, 47-65.

Di Vito, M.A., Isaia, R., Orsi, G., Southon, J., de Vita, S., D'Antonio, M., Pappalardo, L., Piochi, M., 1999. Volcanism and deformation since 12,000 years at the Campi Flegrei caldera (Italy). J. Volcanol. Geotherm. Res. 91, 221-246.

Douka, K., Jacobs, Z., Lane, C., Grün, R., Farr, L., Hunt, C., Inglis, R.H., Reynolds, T., Albert, P., Aubert, M., Cullen, V., Hill, E., Kinsley, L., Roberts, R.G., Tomlinson, E.L., Wulf, S., Barker, G., 2014. The chronostratigraphy of the Haua Fteah cave (Cyrenaica, northeast Libya). J. Hum. Evol. 66, 39-63.

d'Errico, F., Banks, W.E., 2015. Tephra studies and the reconstruction of Middle-toUpper Paleolithic cultural trajectories. Quat. Sci. Rev. 118, 182-193.

Eriksson, A., Betti, L., Friend, A.D., et al., 2012. Late Pleistocene climate change and the global expansion of anatomically modern humans. Proc. Natl. Acad. Sci. U. S. A. $109,16089-16094$.

Fedele, F.G., Giaccio, B., Isaia, R., Orsi, G., 2002. Ecosystem impact of the Campanian Ignimbrite eruption in Late Pleistocene Europe. Quat. Res. 57, 420-424.

Fedele, F.G., Giaccio, B., Hajdas, I., 2008. Timescales and cultural process at $40,000 \mathrm{BP}$ in the light of the Campanian Ignimbrite eruption, Western Eurasia. J. Hum. Evol. 55, 834-857.

Fitzsimmons, K.E., Hambach, U., Veres, D., Iovita, R., 2013. The Campanian Ignimbrite eruption: new data on volcanic ash dispersal and its potential impact on human evolution. PLoS ONE 8. http://dx.doi.org/10.1371/0065839.

Golovanova, L.V., Doronichev, V.B., Cleghorn, N.E., Koulkova, M.A., Sapelko, T.V., Shackley, M.S., 2010. Significance of ecological factors in the Middle to Upper Paleolithic Transition. Curr. Anthropol. 51, 655-691.

Grant, K.M., Rohling, E.J., Bar-Matthews, M., Ayalon, A., Medina-Elizalde, M., Bronk Ramsey, C., Satow, C., Roberts, A.P., 2012. Rapid coupling between ice volume and polar temperature over the past 150,000 years. Nature 491, 744-747.

Griggs, A.J., Davies, S.M., Abbott, P.M., Rasmussen, T.L., Palmer, A.P., 2014. Optimising the use of marine tephrochronology in the North Atlantic: a detailed investigation of the Faroe Marine Ash Zones II, III and IV. Quat. Sci. Rev. 106, 122-139.

Haflidason, H., Eiríksson, J., van Kreveld, S., 2000. The tephrochronology of Iceland and the North Atlantic region during the Middle and Late Quaternary: a review. J. Quat. Sci. 15, 3-22.

Hardiman, M., 2012. Testing and Refining the Chronology and Correlation of Mediterranean Pollen Records of Late Last Glacial Age Using Tephrochronology (Unpublished Ph.D. thesis). University of London, UK.

Hayward, C., 2011. High spatial resolution electron probe microanalysis of tephras and melt inclusions without beam-induced chemical modification. Holocene 22, 119-125.

Hemming, S.R., 2004. Heinrich events: massive late Pleistocene detritus layers of the North Atlantic and their global climate imprint. Rev. Geophys. 42 http:// dx.doi.org/10.1029/2003RG000128.

Herrera, K.J., Somarelli, J.A., Lowery, R.K., Herrera, R.J., 2009. To what extent did Neanderthals and modern humans interact? Biol. Rev. 84, 245-257.

Higham, T., Jacobi, R., Bassell, L., Bronk Ramsey, C., Chiotti, L., Nespoulet, R., 2011. Precision dating of the Palaeolithic: a new radiocarbon chronology for the Abri Pataud (France), a key Aurignacian sequence. J. Hum. Evol. 61, 549-563.

Higham, T., Bassell, L., Jacobi, R., Wood, R., Bronk Ramsey, C., Conard, N.J., 2012. Testing models for the beginnings of the Aurignacian and the advent of figurative art and music: the radiocarbon chronology of Geißenklösterle. J. Hum. Evol. 62, 664-676.

Hoffecker, J.F., 2009. The spread of modern humans in Europe. Proc. Natl. Acad. Sci. U. S. A. 106, 16040-16045.

Housley, R.A., Gamble, C.S., RESET Associates, 2015. Examination of Late Palaeolithic archaeological sites in northern Europe for the preservation of cryptotephra layers. Quat. Sci. Rev. 118, 142-150.

Housley, R.A., MacLeod, A., Nalepka, D., Jurochnik, A., Masojć, M., Davies, L., Lincoln, P.C., Bronk Ramsey, C., Gamble, C.S., Lowe, J.J., 2013. Tephrostratigraphy of a Lateglacial lake sediment sequence at Wegliny, southwest Poland. Quat. Sci. Rev. 77, 4-18.

Hublin, J.-J., 2012. The earliest modern human colonization of Europe. Proc. Natl. Acad. Sci. U. S. A. 109, 13471-13472.

Hublin, J.-J., 2015. The modern human colonization of western Eurasia: when and where? Quat. Sci. Rev. 118, 194-210.

Ikehara, K., Danhara, T., Yamashita, T., Tanahashi, M., Morita, S., Ohkushi, K., 2011. Paleoceanographic control on a large marine reservoir effect offshore of Tokai, south of Japan, NW Pacific, during the Last Glacial maximum-deglaciation. Quat. Int. 246, 213-221.

Insinga, D.D., Tamburrino, S., Lirer, F., Vezzoli, L., Barra, M., De Lange, G.J., Tiepolo, M., Vallefuoco, M., Mazzola, S., Sprovieri, M., 2014. Tephrochronology of the astronomically-tuned KC01B deep-sea core, Ionian Sea: insights into the explosive activity of the Central Mediterranean area during the last $200 \mathrm{ka}$. Quat. Sci. Rev. 85, 63-84.

Jensen, B.J.L., Pyne-O'Donnell, S., Plunkett, G., Froese, D.G., Hughes, P.D.M., et al., 2014. Transatlantic distribution of the Alaskan White River Ash. Geology 42, 875-878. 
Jochum, K.P., Stoll, B., Herwig, K., Willbold, M., Hofmann, A.W., 2006. MPI-DING reference glasses for in situ microanalysis: new reference values for element concentrations and isotope ratios. Geochem. Geophys. Geosyst. 7 http:// dx.doi.org/10.1029/2005GC001060.

Karkanas, P., White, D., Lane, C.S., Stringer, C., Davies, W., Cullen, V.L., Smith, V.C., Ntinou, M., Tsartsidou, G., Kyparissi-Apostolika, N., 2015. Tephra correlations and climatic events between the MIS6/5 transition and the beginning of MIS3 in Theopetra Cave, central Greece. Quat. Sci. Rev. 118, 170-181.

Keller, J., Ryan, W.B.F., Ninkovich, D., Altherr, R., 1978. Explosive volcanic activity in the Mediterranean over the past 200,000 years as recorded in deep sea sediments. Bull. Geol. Soc. Am. 89, 591-604.

Kuehn, S.C., Foit Jr., F.F., 2006. Correlation of widespread Holocene and Pleistocene tephra layers from Newberry Volcano, Oregon, USA, using glass compositions and numerical analysis. Quat. Int. 148, 113-137.

Lacasse, C., Garbe-Schönberg, C.D., 2001. Explosive silicic volcanism in Iceland and the Jan Mayen area during the last $6 \mathrm{Ma}$ : sources and timing of major eruptions. J. Volcanol. Geotherm. Res. 107, 113-147.

Lane, C.S., Blockley, S.P.E., Bronk Ramsey, C., Lotter, A.F., 2011a. Tephrochronology and absolute centennial scale synchronisation of European and Greenland records for the Last Glacial to Interglacial transition: a case study of Soppensee and NGRIP. Quat. Int. 246, 145-156.

Lane, C.S., Andriè, M., Cullen, V.L., Blockley, S.P.E., 2011b. The occurrence of distal Icelandic and Italian tephra in the Lateglacial of Lake Bled, Slovenia. Quat. Sci. Rev. 30, 1013-1018.

Lane, C.S., Blockley, S.P.E., Lotter, A.F., Finsinger, W., Filippi, M.L., Matthews, I.P., 2012a. A regional tephrostratigraphic framework for central and southern European climate archives during the Last Glacial to Interglacial Transition: comparisons north and south of the Alps. Quat. Sci. Rev. 36, 50-58.

Lane, C.S., Blockley, S.P.E., Mangerud, J., Smith, V.C., Lohne, O.S., Tomlinson, E.L., Matthews, I.P., Lotter, A.F., 2012b. Was the 12.1 ka Icelandic Vedde Ash one of a kind? Quat. Sci. Rev. 33, 87-99.

Lane, C.S., Brauer, A., Blockley, S.P.E., Dulski, P., 2013. Volcanic ash reveals timetransgressive abrupt climate change during the Younger Dryas. Geology 41, 1251-1254.

Lane, C.S., Cullen, V.L., White, D., Bramham-Law, C.W.F., Smith, V.C., 2014. Cryptotephra as a dating and correlation tool in archaeology. J. Archaeol. Sci. 42, 42-50.

Lane, C.S., Brauer, A., Blockley, S.P.E., Martin-Puertas, C., Smith, V.C., Tomlinson, E.L., February 2015. The Late Quaternary tephrostratigraphy of annually laminated sediments from Meerfelder Maar, Germany. Quat. Sci. Rev. (Submitted).

Llave, E., Schönfield, J., Hernández-Molina, F.J., Mulder, T., Somoza, L., Díaz del Río, V., Sánchez-Almazo, I., 2006. High-resolution stratigraphy of the Mediterranean outflow contourite system in the Gulf of Cadiz during the late Pleistocene: the impact of Heinrich events. Mar. Geol. 227, 241-262.

Lowe, D.J., 2008. Globalization of tephrochronology: new views from Australia. Prog. Phys. Geogr. 32, 311-335.

Lowe, D.J., 2011. Tephrochronology and its application: a review. Quat. Geochronol. $6,107-153$.

Lowe, J.J., 2001. Abrupt climatic changes in Europe during the Last GlacialInterglacial transition: the potential for testing hypotheses on the synchroneity of climatic events using tephrochronology. Glob. Planet. Change 30, 73-84.

Lowe, J.J., Walker, M.J.C., 2015a. Reconstructing Quaternary Environments, third ed. Routledge (Taylor \& Francis Group), London \& New York.

Lowe, J.J., Walker, M.J.C., 2015b. Measuring Quaternary time: a 50-year perspective. J. Quat. Sci. 30, 104-113.

Lowe, J.J., Blockley, S., Trincardi, F., Asioli, A., Cattaneo, A., Matthews, I.P., Pollard, M., Wulf, S., 2007. Age modelling of late Quaternary marine sequences in the Adriatic: towards improved precision and accuracy using volcanic event stratigraphy. Cont. Shelf Res. 27, 560-582.

Lowe, J., Barton, N., Blockley, S., Ramsey, C.B., Cullen, V.L., Davies, W., Gamble, C., Grant, K., Hardiman, M., Housley, R., Lane, C.S., Lee, S., Lewis, M., MacLeod, A., Menzies, M., Müller, W., Pollard, M., Price, C., Roberts, A.P., Rohling, E.J., Satow, C., Smith, V.C., Stringer, C.B., Tomlinson, E.L., White, D., Albert, P., Arienzo, I., Barker, G., Borić, D., Carandente, A., Civetta, L., Ferrier, C., Guadelli, J., Karkanas, P., Koumouzelis, M., Müller, U.C., Orsi, G., Pross, J., Rosi, M., Shalamanov-Korobar, L., Sirakov, N., Tzedakis, P.C., 2012. Volcanic ash layers illuminate the resilience of Neanderthals and early modern humans to natural Hazards. Proc. Natl. Acad. Sci. U. S. A. 109, 13532-13537.

MacLeod, A., Brunnberg, L., Wastegård, S., Hang, T., Matthews, I.P., 2014. Lateglacial cryptotephra detected within clay varves in Östergötland, south-east Sweden. J. Quat. Sci. 29, 605-609.

Matthews, I.P., Birks, H.H., Bourne, A., Brooks, S., Lowe, J.J., MacLeod, A., PyneO'Donnell, S., 2011. New age estimates and climatostratigraphic correlations for the Borrobol and Penifiler Tephras: evidence from Abernethy Forest, Scotland. J. Quat. Sci. Rapid Commun. 26, 247-252.

Matthews, I.P., Trincardi, F., Lowe, J.J., Bourne, A.J., MacLeod, A., Abbott, P.M., Andersen, N., Asioli, A., Blockley, S.P.E., Lane, C.S., Oh, Y.A., Satow, C.S., Staff, R.A., Wulf, S., 2015. Developing a robust tephrochronological framework for Late Quaternary marine records in the Southern Adriatic Sea: new data from core station SA03-11. Quat. Sci. Rev. 118, 84-104.

Morabito, S., Petrosino, P., Milia, A., Sprovieri, M., Tamburrino, S., 2014. A multidisciplinary approach for reconstructing the stratigraphic framework for the last 40 ka in a bathyal area of the eastern Tyrrhenian Sea. Quat. Sci. Rev. 123, $121-138$.
Morley, M.W., Woodward, J.C., 2011. The Campanian Ignimbrite (Y5) tephra at Crvena Stijena Rockshelter, Montenegro. Quat. Res. 75, 683-696.

Narcisi, B., Petit, J.R., Delmonte, B., Basile-Doelsch, I., Maggi, V., 2005. Characteristics and sources of tephra layers in the EPICA-Dome C ice record (East Antarctica): implications for past atmospheric circulation and ice core stratigraphic correlations. Earth Planet. Sci. Lett. 239, 253-265.

Olsen, J., Rasmussen, T.L., Reimer, P.J., 2014. North Atlantic marine radiocarbon reservoir ages through Heinrich event H4: a new method for marine age mode construction. J. Geol. Soc. Spec. Publ. 398 http://dx.doi.org/10.1144/SP398.2.

Paterne, M., Guichard, F., Labeyrie, J., 1988. Explosive activity of the south Italian volcanoes during the past 80,000 years as determined by marine tephrochronology. J. Volcanol. Geotherm. Res. 34, 153-172.

Pearce, N.J.G., Denton, J.S., Perkins, W.T., Westgate, J.A., Alloway, B.V., 2007. Correlation and characterisation of individual glass shards from tephra deposits using trace element laser ablation ICP-MS analyses: current status and future potential. J. Quat. Sci. 22, 721-736.

Pearce, N.J.G., Abbott, P.M., Martin-Jones, C., 2014. Microbeam methods for the analysis of glass in fine-grained tephra deposits: a SMART perspective on current and future trends. Geol. Soc. Lond. Spec. Publ. 398, 29-46.

Pyle, D.M., Ricketts, G.D., Margan, V., van Andel, T.H., Sinitsyn, A.A., Praslov, N.D. Lisitsyn, S., 2006. Wide dispersal and deposition of distal tephra during the Pleistocene 'Campanian Ignimbrite/Y5' eruption, Italy. Quat. Sci. Rev. 25 2713-2728.

Rasmussen, S.O., Andersen, K.K., Svensson, A.M., Steffensen, J.P., Vinther, B.M., Clausen, H.B., Siggaard-Andersen, M.-L., Johnsen, S.J., Larsen, L.B., DahlJensen, D., Bigler, M., Röthlisberger, R., Fischer, H., Goto-Azuma, K., Hansson, M.E., Ruth, U., 2006. A new Greenland ice core chronology for the Last Glacial termination. J. Geophys. Res. 111, 06110.01029/02005JD006079.

Rasmussen, S.O., Bigler, M., Blockley, S.P.E., Blunier, T., Buchardt, S.L., Clausen, H.B. Cvijanovic, I., Dahl-Jensen, D., Johnsen, S.J., Fischer, H., Gkinis, V., Guillevic, M., Hoek, W.Z., Lowe, J.J., Pedro, J.L., Popp, T., Seierstad, I.K., Steffensen, J.P., Svensson, A.M., Vellelonga, P., Winther, B.M., Walker, M.J.C., Wheatley, J.J., Winstrup, M., 2014. A stratigraphic framework for abrupt climatic changes during the Last Glacial period based on three synchronized Greenland ice-core records: refining and extending the INTIMATE event stratigraphy. Quat. Sci. Rev. $106,14-28$.

Richerson, P.J., Boyd, R., Bettinger, R.L., 2009. Cultural innovations and demographic change. Hum. Biol. 81, 211-235.

Riede, F., Bazely, O., Newton, A.J., Lane, C.S., 2011. A Laacher See-eruption supplement to Tephrabase. Investigating distal tephra fall-out dynamics. Quat. Int. 246, 134-144.

Satow, C., Tomlinson, E.L., Grant, K.M., Albert, P.G., Smith, V.C., Manning, C.J., Ottolini, L., Wulf, S., Rohling, E.J., Lowe, J.J., Blockley, S.P., Menzies, M.A., 2015. Tephrostratigraphy of the last 166,000 years in the south-eastern Aegean Sea (sediment core LC21). Quat. Sci. Rev. 117, 96-112.

Seierstad, I.K., Bigler, M., Blunier, T., Bourne, A., Brook, E., Buchardt, S.L., Buizert, C., Clausen, H.B., Cook, E., Dahl-Jensen, D., Davies, S., Guillevic, M., Johnsen, S.J., Pedersen, D.S., Popp, T.J., Rasmussen, S.O., Severinghaus, J., Svensson, A., Vinther, B.M., 2014. Consistently dated records from the Greenland GRIP, GISP2 and NGRIP ice cores for the past 104 ka reveal regional millennial-scale isotope gradients with possible Heinrich Event imprint. Quat. Sci. Rev. 106, 29-46.

Shane, P., 2005. Towards a comprehensive distal andesitic tephrostratigraphic framework for New Zealand based on eruptions from Egmont volcano. J. Quat. Sci. 20, 45-57.

Siani, G., Sulpizio, R., Paterne, M., Sbrana, A., 2004. Tephrostratigraphy study for the last 18,000 C-14 years in a deep-sea sediment sequence for the South Adriatic. Quat. Sci. Rev. 23, 2485-2500.

Smith, F.H., Jankovic, I., Karavanic, I., 2005. The assimilation model, modern human origins in Europe, and the extinction of Neandertals. Quat. Int. 137, 7-19.

Steffensen, J.P., Andersen, K.K., Bigler, M., et al., 2008. High-resolution Greenland ice-core data show abrupt climatic change happens in a few years. Science 321, 680-684.

Stringer, C., 2011. The Origin of Our Species. Allen Lane.

Thornalley, D.J.R., McCave, I.N., Elderfield, H., 2011. Tephra in deglacial ocean sediments south of Iceland: stratigraphy, geochemistry and oceanic reservoir ages. J. Quat. Sci. 26, 190-198.

Tomlinson, E.L., Thordarson, T., Müller, W., Thirlwall, M.F., Menzies, M.A., 2010. Microanalysis of tephra by LA-ICP-MS - strategies, advantages and limitations assessed using the Thorsmörk Ignimbrite (Southern Iceland). Chem. Geol. 279, 73-89.

Tomlinson, E.L., Arienzo, I., Civetta, L., Wulf, S., Smith, V.C., Hardiman, M., Lane, C.S., Carandente, A., Orsi, G., Rosi, M., Müller, W., Menzies, M.A., 2012a. Geochemistry of the Phlegraean Fields (Italy) proximal sources for major Mediterranean Tephras: implications for the dispersal of Plinian \& co-Ignimbritic components of explosive eruptions. Geochim. Cosmochim. Acta 93, 102-128.

Tomlinson, E.L., Kinvig, H.S., Smith, V.C., Blundy, J.D., Gottsmann, J., Müller, W. Menzies, M.A., 2012b. The upper and lower Nisyros Pumices: revisions to the Mediterranean tephrostratigraphic record based on Micron-beam glass geochemistry. J. Volcanol. Geotherm. Res. 243-244, 69-80.

Tomlinson, E.L., Thordarson, T., Lane, C.S., Smith, V.C., Manning, C.J., Müller, W., Menzies, M.A., 2012c. Petrogenesis of the Sólheimar Ignimbrite (Katla, Iceland): implications for tephrostratigraphy. Geochim. Cosmochim. Acta 86, $318-337$.

Tomlinson, E.L., Albert, P.G., Wulf, S., Brown, R.J., Smith, V.C., Keller, J., Orsi, G., Bourne, A.J., Menzies, M., 2014. Age and geochemistry of tephra layers from 
Ischia, Italy: constraints from proximal-distal correlations with Lago Grande di Monticchio. J. Volcanol. Geotherm. Res. 287, 22-39.

Tomlinson, E.L., Smith, V.C., Albert, P.G., Aydar, E., Civetta, L., Cioni, R., Çubukçu, E., Gertisser, R., Isaia, R., Menzies, M.A., Orsi, G., Rosi, M., Zanchetta, G., 2015. The major and trace element glass compositions of the productive Mediterranean volcanic sources: tools for correlating distal tephra layers in and around Europe. Quat. Sci. Rev. 118, 48-66.

Trinkaus, E., 2005. Early modern humans. Annu. Rev. Anthropol. 34, 207-230.

Tryon, C.A., Logan, M.A.V., Mouralis, D., Kuhn, S., Slimak, L., Balkan-Atli, N., 2009. Building a tephrostratigraphic framework for the Paleolithic of central Anatolia, Turkey. J. Archaeol. Sci. 36, 637-652.

Turney, C.S.M., Lowe, J.J., Davies, S.M., Hall, V., Lowe, D.J., Wastegard, S., Hoek, W., Alloway, B., SCOTAV and INTIMATE Members, 2004. Tephrochronology of Last Termination sequences in Europe: a protocol for improved analytical precision and robust correlation procedures (a joint SCOTAV-INTIMATE proposal) J. Quat. Sci. 19, 111-120.

Tzedakis, P.C., Hughen, K.A., Cacho, I., Harvati, K., 2007. Placing late Neanderthals in a climatic context. Nature 449, 206-208.

Van den Bogaard, C., Jensen, B.J.L., Pearce, N.J.G., Froese, D.G., Portnyagin, M.V., Ponomareva, V.V., Garbe-Schönberg, D., Wennrich, V., 2013. Volcanic ash layers in Lake El'gygytgyn: eight new regionally significant chronostratigraphic markers for western Beringia. Clim. Past Discuss. 9, 5977-6034.

Vogel, H., Zanchetta, G., Sulpizio, R., Wagner, B., Nowaczyk, N., 2010. A tephrostratigraphic record for the Last Glacial-Interglacial cycle from Lake Ohrid, Albania and Macedonia. J. Quat. Sci. 25, 320-338.

Wastegård, S., Veres, D., Kliem, P., Hahn, A., Ohlendorf, C., Zolitschka, B., The PASADO Science Team, 2013. Towards a tephrochronological framework for the southernmost part of South America - the Laguna Potrok Aike tephra record. Quat. Sci. Rev. 71, 81-90.

Weninger, B., Clare, L., Rohling, E.J., Bar-Yosef, O., Böhner, U., Budja, M. Bundschuh, M., Feurdean, A., Gebel, H.-G., Jöris, O., Linstädter, A., Mayewski, P., Mühlenbruch, T., Reingruber, A., Rollefson, G., Schyle, D., Thissen, L. Todorova, H., Zielhofer, C., 2009. The impact of rapid climate change on prehistoric societies during the Holocene in the eastern Mediterranean. Doc. Praehist. XXXVI, 7-59.

Wood, RE Barroso-Ruíz C Caparrós, M. Jordá Parda, JF Santos, B.G. Higham, T.F.G., 2013. Radiocarbon dating casts doubt on the late chronology of the Middle to Upper Palaeolithic transition in southern Iberia. Proc. Natl. Acad. Sci. 110, 2781-2786.

Wulf, S., Brauer, A., Kraml, M., Keller, J., Negendank, J.F.W., 2004. Tephrochronology of the 100 ka lacustrine sediment record of Lago Grande di Monticchio (southern Italy). Quat. Int. 122, 7-30.

Wulf, S., Kraml, M., Keller, J., 2008. Towards a detailed distal tephrostratigraphy in the Central Mediterranean: the last 20,000 yrs record of Lago Grande di Monticchio. J. Volcanol. Geotherm. Res. 177, 118-132.

Wulf, S., Keller, J., Paterne, M., Mingram, J., Lauterbach, S., Opitz, S., Sottili, G., Giaccio, B., Albert, P.G., Satow, C., Tomlinson, E.L., Viccaro, M., Brauer, A., 2012 The 100-133 ka record of Italian explosive volcanism and revised tephrochronology of Lago Grande Di Monticchio. Quat. Sci. Rev. 58, 104-123.

Wutke, K., Wulf, S., Tomlinson, E.L., Hardiman, M., Dulski, P., Luterbacher, J., Brauer, A., 2015. Geochemical properties and environmental impacts of seven Campanian tephra layers deposited between 60 and $38 \mathrm{ka}$ BP in the varved lake sediments of Lago Grande di Monticchio, southern Italy. Quat. Sci. Rev. 118, $67-83$. 